\title{
Article
}

\section{The influence of microscale lithological layering and fluid availability on the metamorphic development of garnet and zircon: insights into dissolution-reprecipitation processes}

\author{
Tara R. McElhinney ${ }^{1,2 *}$ (D), Tim J. Dempster ${ }^{2}$ and Peter Chung ${ }^{2}$ \\ ${ }^{1}$ Department of Materials, University of Manchester, Manchester, UK; and ${ }^{2}$ Department of Earth Sciences, University of Glasgow, Glasgow, UK
}

\begin{abstract}
The response of garnet and zircon to prograde amphibolite-facies metamorphism in late Proterozoic mica schists from the Scottish Highlands has been investigated. Spatial analysis of zircon populations using scanning electron microscopy was undertaken in Dalradian Schists that have undergone a sequence of prograde garnet growth and localised breakdown reactions involving coupled dissolution-reprecipitation. Fluid availability and matrix permeability strongly control this metamorphic response and different generations of garnet contain radically different populations of metamorphic micro-zircon and associated changes in the detrital zircon population. Micro-zircon abundance increases during garnet growth, whereas that of detrital zircon decreases. The mineralogy of the matrix influences zircon abundance in porphyroblast phases, where garnet overgrows a micaceous matrix zircon-rich garnet forms and where it overgrows a quartzofeldspathic matrix the result is zircon-poor garnet. Following garnet growth, micro-zircon abundance decreases at each stage of the prograde reaction history, with sillimanite-zone schists containing the lowest abundance, suggesting micro-zircons are texturally less stable at staurolite- and sillimanite-grade metamorphism. Micro-zircons are distributed evenly across host minerals in the matrix, with the exception of retrograde chlorite where micro-zircons are absent due to fluids removing Zr before new zircon can precipitate. There is an overall decrease in the mode of zircon at each stage of the reaction history, indicating that zircon is a highly reactive phase during amphibolite-facies metamorphism and is very sensitive to individual prograde and retrograde reactions.
\end{abstract}

Keywords: micro-zircon, garnet, coupled dissolution-reprecipitation, regional metamorphism

(Received 6 August 2021; accepted 6 December 2021; Accepted Manuscript published online: 13 December 2021; Associate Editor: Thomas Mueller)

\section{Introduction}

Dissolution-reprecipitation occurs when a fluid comes into contact with a mineral with which it is undersaturated, resulting in the dissolution of the less stable parent phase and reprecipitation of a more stable daughter phase (Putnis and Putnis, 2007; Putnis, 2009; Ruiz-Agudo et al., 2014; Altree-Williams et al., 2015; Konrad-Schmolke et al., 2018). Spatial coupling of dissolution and reprecipitation commonly occurs, where an interfacial fluid film at the reaction front becomes saturated resulting in precipitation of a stable daughter phase at the reaction surface of the unstable parent phase (Putnis, 2009; Ruiz-Agudo et al., 2014). Within regional metamorphic garnet, coupled dissolutionreprecipitation processes may be fingerprinted, producing a compositionally and texturally distinct garnet (Martin et al., 2011; Dempster et al., 2017; Dempster et al., 2019). Garnet is characterised by sluggish volume diffusion at amphibolite-facies

\footnotetext{
*Author for correspondence: Tara R. McElhinney, Email: tara.mcelhinney@postgrad. manchester.ac.uk

Cite this article: McElhinney T.R., Dempster T.J. and Chung P. (2022) The influence of microscale lithological layering and fluid availability on the metamorphic development of garnet and zircon: insights into dissolution-reprecipitation processes. Mineralogical Magazine 86, 9-26. https://doi.org/10.1180/mgm.2021.97
}

conditions and can record changing $P-T-X$ (pressure, temperature, composition) during growth and post-growth modification (Jiang and Lasaga, 1990; Spear, 1991; Raimondo et al., 2017).

This study examines the behaviour of zircon in a prograde regional metamorphic sequence of pelitic schists from the Scottish Highlands. Garnet in these schists has been studied previously (Dempster et al., 2017; 2019), and the garnet characteristics defined in these studies have been used as a context for understanding the reaction history. Primary clear garnet is inclusion-poor and represents essentially unmodified porphyroblasts, whereas cloudy garnet develops locally, and has been texturally and compositionally modified by coupled dissolutionreprecipitation (Martin et al., 2011; Dempster et al., 2017). Such garnet contains large, irregularly-shaped quartz inclusions and abundant small, sub-rounded fluid inclusions (Martin et al., 2011; Dempster et al., 2017). At higher temperatures, the cloudy texture of garnet may be eliminated, and the porphyroblast composition further modified producing secondary clear garnet (Dempster et al., 2019). Secondary clear garnet forms as rims at porphyroblast margins and surrounding mineral inclusions, these re-equilibrated secondary rims are more texturally and compositionally homogeneous than primary clear and cloudy garnet. Garnet is one of the most studied minerals in metamorphic

(C) The Author(s), 2022. Published by Cambridge University Press on behalf of The Mineralogical Society of Great Britain and Ireland. This is an Open Access article, distributed under the terms of the Creative Commons Attribution licence (http://creativecommons.org/licenses/by/4.0/), which permits unrestricted re-use, distribution and reproduction, provided the original article is properly cited. 
petrology (Hollister, 1966; Yardley, 1977; Dempster, 1985; Hames and Menard, 1993; Carlson, 2006; Baxter et al., 2017), making it the perfect canvas to understand the behaviour of zircon during metamorphism.

Zircon is viewed traditionally as a physically and chemically unreactive mineral, highly resistant to metamorphism except at very high temperatures (Poldevaart, 1955; Gastil et al., 1967). A number of studies report evidence of zircon reacting across a range of metamorphic conditions (Hoskin and Black, 2000; Rubatto et al., 2001; Williams, 2001; Dempster et al., 2004; Rasmussen, 2005; Rubatto and Hermann, 2007; Dempster et al., 2008; Hay and Dempster, 2009; Vonlanthen et al., 2012; Dempster and Chung, 2013; Wang et al., 2014), raising questions about factors that promote zircon reactivity. Zircon growth during metamorphism can occur as outgrowths on detrital grains (e.g. Hay and Dempster, 2009) or as discrete very fine $(<3 \mu \mathrm{m})$ zircon termed 'micro-zircon' (Dempster et al., 2004; Dempster et al., 2008). In this work zircon populations are analysed from schists containing unmodified garnet, cloudy garnet modified during staurolite growth and re-equilibrated clear garnet formed during sillimanite growth to understand the effect each stage of the reaction history has on zircon behaviour.

\section{Geological setting}

This study analyses polymetamorphic Leven Schists from the Appin Group in Glen Roy, Scotland. Garnet- and staurolite-zone schists were from NN29861 85668 (UK Ordnance Survey Grid Reference), whereas sillimanite-zone schists were from the north side of Glen Roy NN2671 9289. The samples consist of finegrained interbedded micaceous and quartzofeldspathic metasedimentary rocks with 1-4 $\mathrm{mm}$ garnet porphyroblasts (Dempster et al., 2017). Such matrix layers range from $<0.2 \mathrm{~mm}$ up to $3 \mathrm{~mm}$ thick. The Appin Group rocks age is determined to be $656 \pm 9 \mathrm{Ma}$, using Re-Os geochronology, representing the age of sedimentation (Rooney et al., 2011). The rocks have undergone complex tectonothemal evolution during the Grampian Orogeny in the Late Neoproterozoic and Early Cambrian (Phillips and Key, 1992; Strachan et al., 2002; Vorhies et al., 2013). The extent of Precambrian metamorphism is unknown (Dempster et al., 2002; Hutton and Alsop, 2004). Peak metamorphism of the Leven Schists at Glen Roy is estimated at between $500-600^{\circ} \mathrm{C}$ and 5-8 kbar (Richardson and Powell, 1976; Wells, 1979; Powell and Evans, 1983; Phillips and Key, 1992).

\section{Methods}

Analytical methods involved transmitted light microscopy (TLM) and scanning electron microscopy (SEM) of polished sections. TLM was used predominantly for initial petrographic analysis, to highlight the areas of interest for SEM, and when analysing inclusion alignment on multiple planes.

Energy dispersive spectroscopy analysis using the Carl-Zeiss Sigma VP electron microscope at University of Glasgow, operated at $20 \mathrm{kV}$ was undertaken to analyse the composition of garnet. Porphyroblasts were mapped and compositional data extrapolated as line transects using AZtec 3.0 Oxford Instruments software to produce quantitative data. Following the removal of mineral inclusions from transects, running averages were used to smooth compositional profiles and reduce analytical noise. Back-scattered electron (BSE) imaging was used to capture garnet surface features including mineral inclusions, fluid inclusions and fractures. Mineral inclusion abundance in garnet was calculated in vol.\% using java analysis on BSE images using ImageJ2, where colour thresholds were adjusted to capture the abundance of different phases.

Zircon abundance and morphology was characterised using an FEI Quanta 200F environmental SEM, at the University of Glasgow, to capture BSE images and map zircon populations. It was operated at $20 \mathrm{kV}$ and moderate beam currents of $26 \mu \mathrm{A}$ with a dwell time of $100 \mu$ s at $1500 \times$ magnification to image the smallest observable micro-zircon, $\sim 10 \mathrm{~nm}$ wide. Brightness and contrast was adjusted to ensure micro-zircons were identifiable from other high mean atomic number features and spot analyses was used on every suspected zircon to ensure accurate identification. Transects and entire porphyroblasts of garnet were mapped using a series of frames $\sim 100 \mu \mathrm{m}$ wide that were montaged together on Inkscape producing a map of the analysed area. From this map quantitative data were extracted through Inkscape, producing data on zircon morphology and abundance. To assess micro-zircon abundance relative to fractures, a coordinate grid was produced over a BSE image map of garnet in which the location of all micro-zircons were identified and an equal number of randomly generated coordinates was produced and plotted. The distance from both populations of micro-zircons to the nearest fracture was then measured in $\mu \mathrm{m}$, allowing a comparison of actual micro-zircon distribution versus randomly generated points.

Where average values are quoted e.g. average size of zircon within a domain, the standard deviation is to $1 \sigma$. Average size values produce large errors and a much larger sample size would be required to produce robust average sizes. Hence size distribution is discussed instead throughout this investigation. In total $\sim 26 \mathrm{~mm}^{2}$ of the schists were analysed, $22.3 \mathrm{~mm}^{2}$ of garnet and $3.6 \mathrm{~mm}^{2}$ of the matrix. Within the staurolite-zone schists six porphyroblasts were imaged, three in staurolite-bearing schist GR01 and three in staurolite-absent schists GR02 and GR07. In the sillimanite-zone schists three garnet porphyroblasts were imaged, one in sillimanite-rich schist UGR0 and two in sillimanite-poor schist UGR1.

\section{Results \\ Petrography}

\section{Staurolite zone}

Three polished sections were selected for analysis on the basis of the varying proportions of staurolite and cloudy garnet (Table 1). The schists are composed of an interbedded quartzofeldspathic and micaceous matrix with garnet, biotite and/or staurolite porphyroblasts (GR01, GR02 and GR07, Table 1).

The micaceous layers display a strong S2 fabric (Fig. 1a). S1 formed early in the metamorphic history during the development of muscovite + biotite + chlorite, whereas S2 developed during the second stage of deformation accompanying the formation of biotite + muscovite + garnet \pm staurolite (Phillips and Key, 1992) . The micaceous matrix is fine grained, $<0.1 \mathrm{~mm}$, with layers dominated by $\sim 65$ vol.\% muscovite (Fig. 1a), with $\sim 25$ vol.\% biotite, and $\sim 5$ vol.\% quartz. Quartzofeldspathic layers are coarser, $\sim 0.25 \mathrm{~mm}$, and are dominated by $\sim 70$ vol.\% quartz and $\sim 20$ vol.\% plagioclase (Fig. 1a).

Garnet is typically $\sim 3 \mathrm{~mm}$ in size, occasionally up to $6 \mathrm{~mm}$, and euhedral-to-subhedral. It commonly has one or more irregular, embayed margins (Fig. 1b). Biotite occurs as a $\sim 0.5 \mathrm{~mm}$ matrix phase and as larger $2-5 \mathrm{~mm}$ porphyroblasts, with retrograde chlorite replacing up to 30 vol.\% of biotite (Fig. 1c). 
Table 1. Modal abundance of constituent minerals in staurolite-zone samples GR01, GR02 and GR05 and in sillimanite-zone samples UGR0 and UGR1.

\begin{tabular}{|c|c|c|c|c|c|}
\hline & \multicolumn{3}{|c|}{ Staurolite zone } & \multicolumn{2}{|c|}{ Sillimanite zone } \\
\hline & GR01 & GR02 & GR05 & UGRO & UGR1 \\
\hline Garnet (clear) & 3.9 & 8.5 & 6.8 & 1.4 & 1.8 \\
\hline Garnet (cloudy) & 5.4 & - & 0.2 & 7 & 3 \\
\hline Muscovite & 33.7 & 23.5 & 38.1 & 37.9 & 39.1 \\
\hline Biotite & 10.3 & 18 & 14.7 & 11.5 & 13.8 \\
\hline Quartz & 27 & 30.1 & 28 & 22.2 & 27.2 \\
\hline Plagioclase & 10.9 & 10.8 & 9.6 & 11.6 & 11.9 \\
\hline Staurolite & 3.7 & - & - & 2.1 & Trace \\
\hline Sillmanite & - & - & - & 1.6 & 0.1 \\
\hline Chlorite & 2.9 & - & 0.5 & 0.5 & 0.5 \\
\hline Monazite & 0.7 & 0.3 & 0.3 & 1.2 & 0.9 \\
\hline Rutile & - & - & - & 0.2 & Trace \\
\hline Allanite & 0.1 & 0.1 & 0.3 & Trace & 0.1 \\
\hline Opaques & 0.8 & 1.7 & 0.5 & 0.7 & 0.7 \\
\hline Cloudy garnet (Vol. \%) & 58.5 & - & 2.9 & 84 & 64 \\
\hline
\end{tabular}

- = not detected

Staurolite is developed in a few of the garnet-bearing schists, immediately adjacent to apparently identical schists lacking staurolite (Dempster et al., 2017). It is typically $<2 \mathrm{~mm}$ in size and forms adjacent to euhedral garnet margins (Fig. 1b), preferentially within a micaceous matrix (Dempster et al., 2017). As the proportion of staurolite increases, so too does the proportion of cloudy garnet (Table 1). During staurolite formation, chlorite is invoked typically as a reactant (Philips and Key, 1992), however in the Glen Roy schists there is no evidence of primary chlorite (Dempster et al., 2017). Instead, in these schists, a small amount of $\mathrm{H}_{2} \mathrm{O}$ is invoked to balance the hydrous component in the following prograde reaction (Dempster et al., 2017):

Fe-rich primary clear garnet + muscovite $+\mathrm{H}_{2} \mathrm{O} \rightarrow$ staurolite + biotite + quartz + cloudy garnet (Dempster et al., 2017).

\section{Sillimanite zone}

Two polished sections were analysed, a sillimanite-poor schist and a sillimanite-rich schist (UGR1, UGR0, Table 1). The matrix of these Leven Schists is also composed of interbedded quartzofeldspathic and micaceous layers with the latter containing the majority of the garnet, biotite and staurolite porphyroblasts. The matrix mineralogy is similar to the staurolite-zone schists, although the fabric is more strongly folded, probably by a third deformation event, S3 (Phillips and Key, 1992) making original planar compositional layering less prominent (Fig. 1d). The schistose matrix is dominantly micaceous with $<1 \mathrm{~mm}$ quartzofeldspathic layers.

Garnet porphyroblasts are $2-4 \mathrm{~mm}$ in size and subhedral, containing irregular and embayed margins. Most garnet porphyroblasts have at least one planar margin, and the proportion of modified cloudy garnet is higher than in the corresponding staurolite-zone schists (Table 1). Biotite occurs as both matrix and porphyroblast forms and replacement by chlorite is limited, with retrogression associated more typically in biotite included in garnet or at the core of atoll garnet structures. Staurolite occurs as two populations: $\sim 3 \mathrm{~mm}$ subhedral-anhedral porphyroblasts forming at margins of garnet; and $<1 \mathrm{~mm}$ euhedral-to-subhedral porphyroblasts in a micaceous matrix.

Sillimanite typically forms fibrolite mats, $0.25-1.5 \mathrm{~mm}$ in diameter, along the margins of garnet in the micaceous matrix (Fig. 1e). Sillimanite also forms mats included within garnet, generally $<0.5 \mathrm{~mm}$ (Fig. 1f), and more rarely occurs as fracture fill close to embayed garnet margins. Sillimanite inclusions are limited to cloudy garnet and are more common in the sillimanite-rich schist, UGR0.

According to the KFMASH $\left(\mathrm{K}_{2} \mathrm{O}-\mathrm{FeO}-\mathrm{MgO}-\mathrm{Al}_{2} \mathrm{O}_{3}-\mathrm{SiO}_{2}-\right.$ $\mathrm{H}_{2} \mathrm{O}$ ) system, reactions involved in sillimanite formation typically involve the consumption of staurolite (Guidotti, 1974; McLellan, 1985), the Glen Roy schists show no evidence of staurolite dissolution (Dempster et al., 2019). Sillimanite is thought to form as a result of the following garnet breakdown reaction:

Cloudy garnet + muscovite $\rightarrow$ sillimanite + biotite + quartz + secondary clear garnet (Dempster et al., 2019).

\section{Characterisations of staurolite-zone garnet}

Garnet in the staurolite-zone schists consists of unmodified primary clear garnet, cloudy garnet and transitional garnet. Cloudy garnet is characterised by the presence of small, aligned fluid inclusions and large, irregularly-shaped quartz inclusions (Dempster et al., 2017). Compositional profiles show disruption to normal garnet zoning associated with the cloudy garnet (Dempster et al., 2017).

\section{Primary clear garnet}

Primary clear garnet has mostly planar margins and few fractures. Such garnet contains few fluid inclusions, $<0.5$ vol.\%, though it hosts a variety of mineral inclusions comprising between 6-27 vol.\%. Quartz is the most abundant inclusion representing $>60$ vol. $\%$ of the population, followed by $\sim 15$ vol. $\%$ ilmenite, $\sim 13$ vol.\% detrital zircon and $<10$ vol.\% allanite. Quartz inclusions display regular margins, are rounded to tabular and are typically $<50 \mu \mathrm{m}$ in size. Ilmenite occurs as two distinct populations; large irregularly-shaped detrital grains $(>50 \mu \mathrm{m})$ and small $(<3 \mu \mathrm{m})$ euhedral grains. Allanite is sub-rounded and most inclusions are $>30 \mu \mathrm{m}$ in size with complex internal textures thought to be due to hydrothermal alteration, locally producing different rare earth element (REE) compositions (Smith et al., 2002; Gros et al., 2020). Zircon inclusions are discussed separately below.

Mineral inclusions form trails aligned with the matrix fabric, typically curved towards the porphyroblast rim (Fig. 2a) indicating syntectonic growth. Mineral inclusions form either quartzrich or ilmenite-rich trails. The former can be traced into the quartzofeldspathic matrix and the latter to the micaceous matrix. There is no consistent change in mineral inclusion abundance or morphology from the garnet core to the rim.

Primary clear garnet has concentric divalent compositional zoning from core to rim (Fig. 2a) typical of growth zoning (Atherton, 1968; Dempster, 1985; Chakraborty and Ganguly, 1991; Gatewood et al., 2015). Manganese concentrations have a bell-shaped profile decreasing from $\sim 15$ mol.\% spessartine in the core to $<1 \mathrm{~mol} \%$ in the rim, whereas $\mathrm{Fe}$ and $\mathrm{Mg}$ display complementary bowl-shaped profiles. Calcium shows a less welldefined concentric pattern though generally mimics $\mathrm{Mn}$, decreasing from core to rim (Fig. 2).

\section{Cloudy garnet}

Cloudy garnet forms bands in staurolite-zone garnet porphyroblasts (Fig. 3a). The extent of cloudiness in porphyroblasts varies, some are entirely clear, others contain $\sim 75 \%$ cloudy garnet. Cloudy garnet contains a high concentration of $10 \mathrm{~s}-100 \mathrm{~s} \mu \mathrm{m}$ sized quartz inclusions and very abundant concentrations of fluid inclusions $<3 \mu \mathrm{m}$ (Fig. 3d). Quartz inclusions are irregularly 
(a)

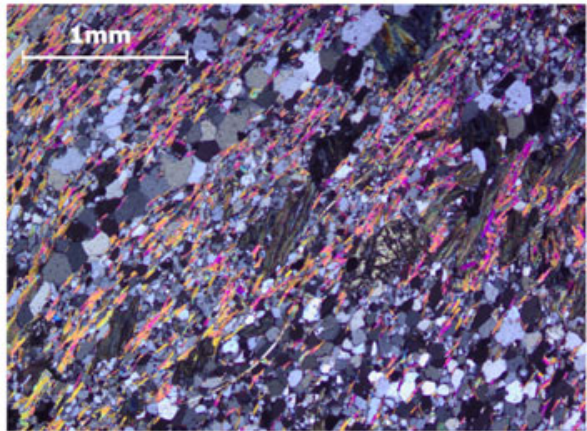

(d)

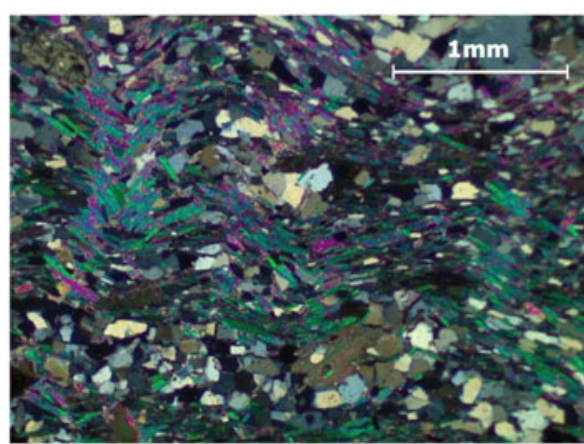

(b)

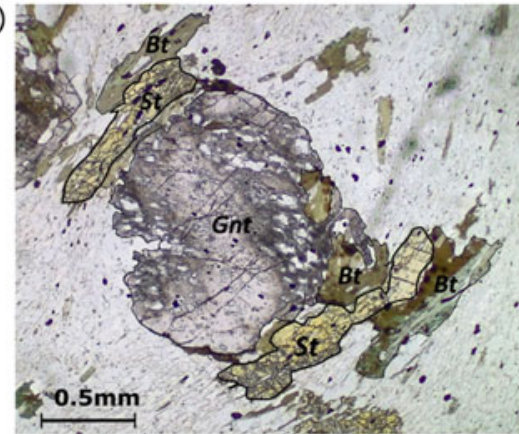

(e)

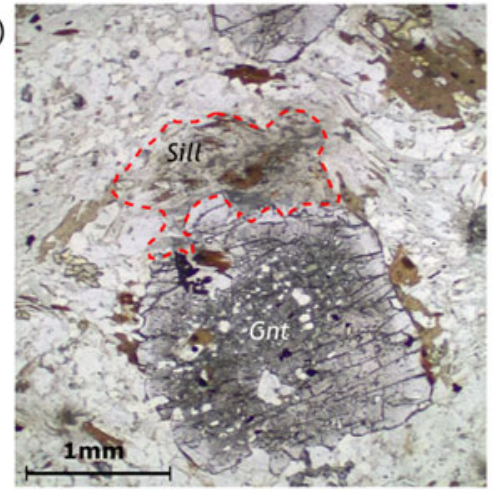

(c)

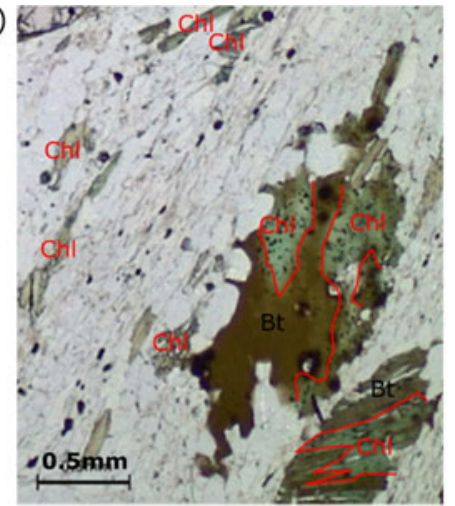

(f)

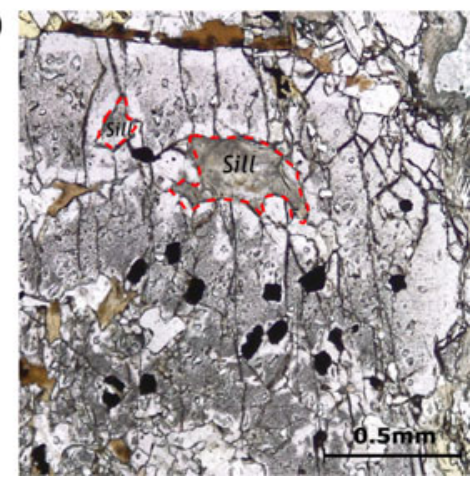

Fig. 1. Photomicrographs of Leven Schists: (a) staurolite-zone matrix composed of interbedded pelite and quartzofeldspathic metasediments; (b) garnet in GR01 with staurolite formation along two margins; (c) retrogression of biotite porphyroblasts and biotite matrix; (d) sillimanite-zone matrix; (e) sillimanite formation as fibrolite mats at garnet margins; (f) fibrolite mat inclusion in garnet.

shaped and display no alignment. Fluid inclusions are rounded to subrounded and trails of inclusions show strong planar alignment (see figure 5a in Dempster et al., 2017) (Fig. 4b), comprising $2-10$ vol.\% of cloudy garnet. Fluid inclusions show one dominant plane of alignment in garnet with another less well-defined plane perpendicular to it (Fig. 4). The dominant alignment is approximately parallel to $\sigma 1$ of the S2 mica fabric and the secondary is parallel to $\sigma 3$ (Fig. 4).

Mineral inclusions include zircon, monazite, quartz, rutile and xenotime. Monazite is the third most abundant mineral inclusion, representing 1.1 vol.\% of cloudy garnet. Monazite inclusions can rarely reach up to $20 \mu \mathrm{m}$, but are more commonly $3-5 \mu \mathrm{m}$ in size. Larger monazite crystals are typically hosted in quartz inclusions and fractures, whereas smaller inclusions are hosted by garnet and more rarely in fluid inclusions. Regarding minerals containing heavy and light rare earth elements (HREE, LREE), cloudy garnet contains no HREE-rich allanite, whereas primary clear garnet contains abundant HREE-rich allanite but no LREE-rich monazite. Cloudy garnet is darker in plane polarised light than clear garnet owing to the high abundance of fluid inclusions (Fig. 3b, c). Such garnet contains a high fracture density, displaying long, $>200 \mu \mathrm{m}$, cross porphyroblast fractures and shorter radial fractures $<100 \mu \mathrm{m}$, typically surrounding inclusions.

Within cloudy garnet, almandine and pyrope components are greater relative to adjacent primary clear garnet $(+7-10 \mathrm{~mol} \% \mathrm{Fe}$, and $+2-4$ mol. $\% \mathrm{Mg}$, respectively). There are lower grossular and spessartine components in cloudy garnet than in primary clear garnet (-6-10 mol.\% Ca, and -5-6 mol.\% Mn (Fig. 2b), respectively). Manganese behaves less consistently than the other cations, occasionally increasing in the outer $100 \mu \mathrm{m}$ at garnet rims.

\section{Transitional garnet}

Transitional garnet forms in areas between cloudy and primary clear garnet and is considered to represent a partially modified intermediate zone $\sim 100 \mu \mathrm{m}$ in width. Transitional garnet generally contains $<1$ vol.\% fluid inclusions, whereas cloudy garnet contains $>1$ vol.\% fluid inclusions and primary clear garnet contains significantly less, generally $<0.1$ vol.\%. There is no change in the size distribution or morphology of fluid inclusions between transitional garnet and cloudy garnet. Transitional garnet contains few mineral inclusions, only rarely containing monazite, quartz and ilmenite. Where present, quartz inclusions in transitional garnet are small, aligned and regularly shaped, consistent with quartz inclusion morphology in primary clear garnet. The fracture density is also similar to that within primary clear garnet i.e. there is an absence of small-scale, interconnected fractures, which are typically abundant in cloudy garnet.

Whereas the texture of transitional garnet is more consistent with primary clear garnet, the composition of these zones is consistent with cloudy garnet (Fig. 2c). Transitional garnet contains high $\mathrm{Mg}$ and $\mathrm{Fe}$, and low $\mathrm{Mn}$ and Ca contents. The compositional change at cloudy-clear margins is gradual, the distance over which the composition changes varies for each cation. Manganese shows the most gradual change over a distance of $50 \mu \mathrm{m}$, whereas Ca shows the sharpest change with composition adjusting over just $15 \mu \mathrm{m}$ (Fig. 2c).

\section{Characteristics of sillimanite-zone garnet}

Sillimanite-zone garnet is composed of primary clear garnet, cloudy garnet and secondary clear garnet. Dempster et al. (2019) 

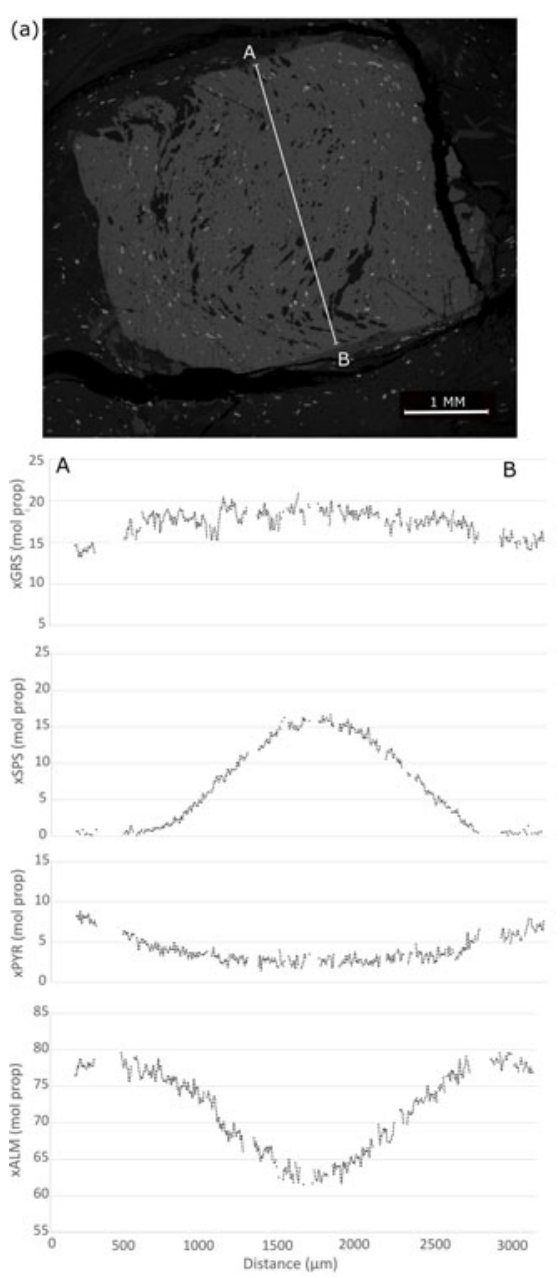
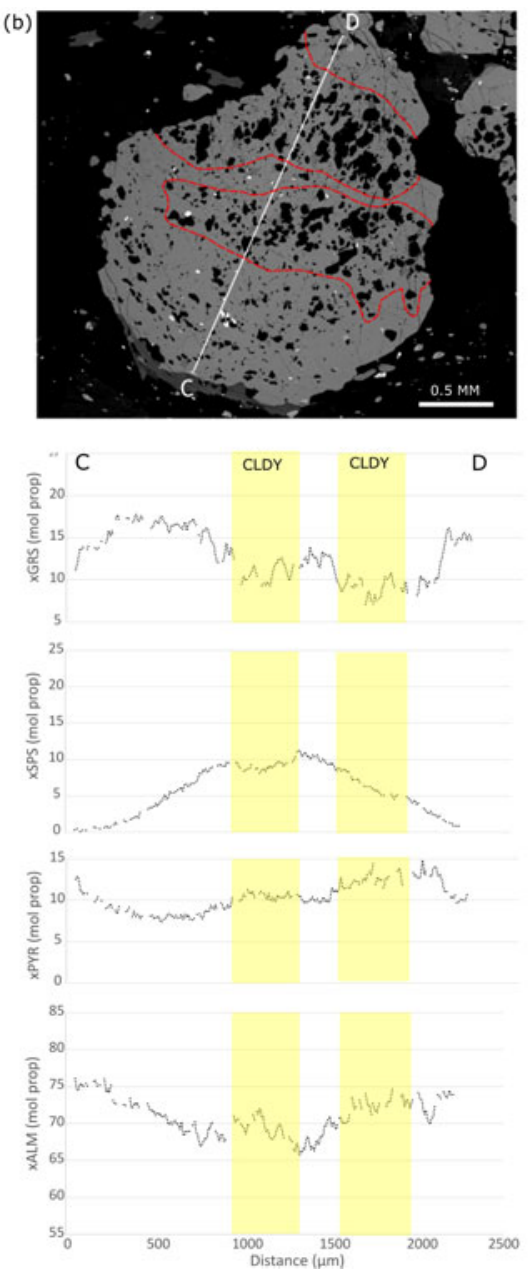
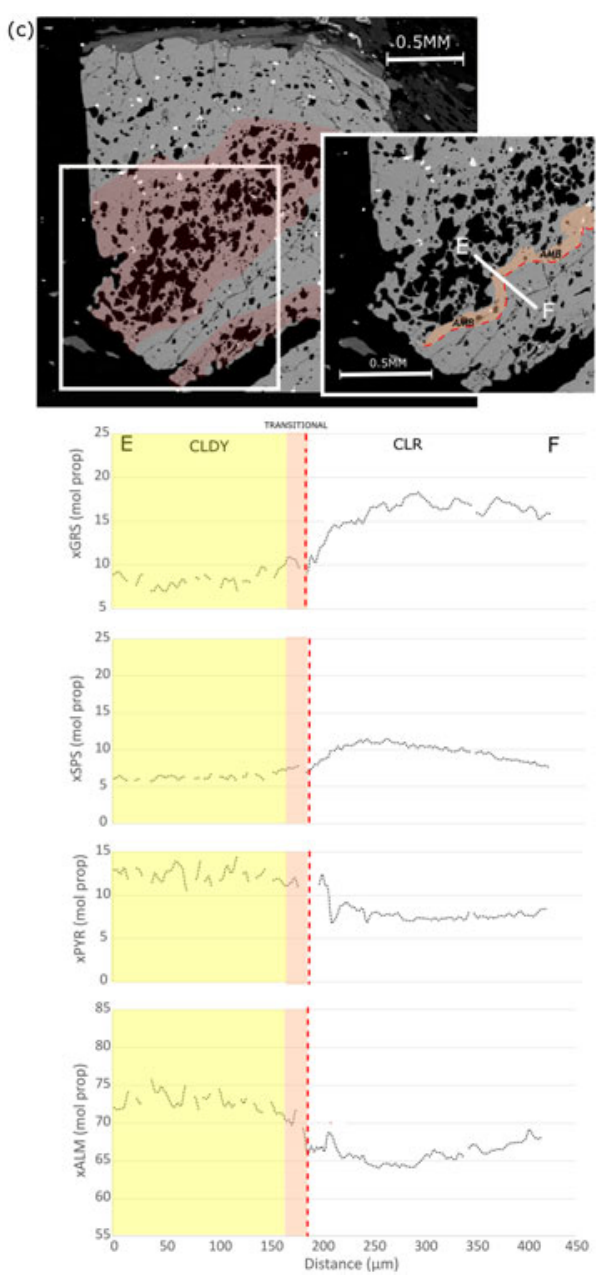

Fig. 2. (a) BSE image and composition of clear garnet porphyroblast GR05-7 across transect A-B; (b) BSE image and compositional transect of garnet porphyroblast GR01-4 across clear garnet (CLR) and cloudy (CLDY) bands (highlighted in yellow) C-D; (c) BSE image and transect E-F across cloudy-clear boundary in GR01-2 capturing transitional garnet (red). Key: xGRS (mol prop) = molecular proportion of Ca-rich grossular, xSPS (mol prop) = molecular proportion of Mn-rich spessartine, $x P Y R=$ molecular proportion of Mg-rich pyrope, $x A L M=$ molecular proportion of Fe-rich almandine.

constrained the textural and compositional characteristics of clear, cloudy and 'texturally re-equilibrated garnet' within the sillimanitezone schists from Glen Roy; the latter is referred to as 'secondary clear garnet' in this study. Transitional garnet is not obvious in the sillimanite-zone schist owing to an uneven distribution of fluid inclusions due to the presence of secondary clear garnet, as such it is not described in the following section.

\section{Primary clear garnet}

The sillimanite-bearing schists contain much less primary clear garnet than within the staurolite schists (Table 1). Garnet within the sillimanite-rich schist UGR0 is composed of just $14 \mathrm{vol} . \%$ primary clear garnet whereas porphyroblasts in the sillimanite-poor UGR1-1 contain 36 vol.\% primary clear garnet. Primary clear garnet is texturally and compositionally identical to that within the staurolite-zone schists.

\section{Cloudy garnet}

The geometry of cloudy zones is generally more regular in sillimanite-zone porphyroblasts than those in the staurolite zone, forming preferentially in the core of porphyroblasts. The texture of cloudy garnet is similar to that in the staurolite-zone schists, with abundant irregularly-shaped quartz inclusions and fluid inclusions. The abundance of the latter is variable, with a mixture of quartz-rich cloudy bands (Fig. 3f) and quartz-poor cloudy garnet (Fig. 3g). The quartz inclusion-rich domains contain up to 70 vol.\% quartz (Fig. 3f), these quartz-rich bands are typically marginal and are present in $\sim 50 \%$ of garnet porphyroblasts in these schists. The quartz-rich domains contain abundant inclusions, such as detrital zircon, monazite and rutile, and increased fracture abundance, predominantly small-scale $<200 \mu \mathrm{m}$ fractures terminating at adjacent inclusions. Fluid-inclusion abundance in quartz-rich domains is typically $<1$ vol.\%. Cloudy garnet outside of quartz-rich bands contain $<20$ vol.\% quartz inclusions. These quartz-poor areas contain a much higher abundance of fluid inclusions (Fig. 3g), more consistent with the staurolite-zone cloudy garnet.

Quartz inclusions are irregularly shaped, typical of cloudy garnet at staurolite-grade conditions, but are relatively small, generally $<100 \mu \mathrm{m}$. Larger quartz inclusions $\sim 500 \mu \mathrm{m}$ are rare, monocrystalline and consistently contain sillimanite inclusions. In addition to quartz there are inclusions of ilmenite, rutile, zircon, monazite and sillimanite. Rutile inclusions are more abundant $\sim 1.2$ vol.\% in sillimanite-zone garnet and the proportion of 
(a)

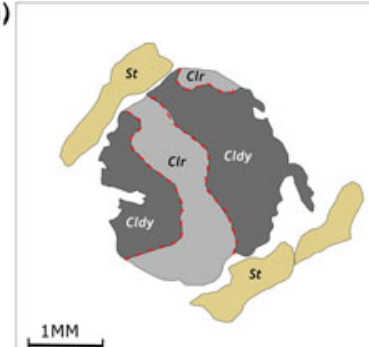

(b)

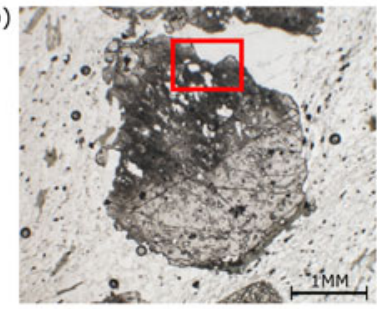

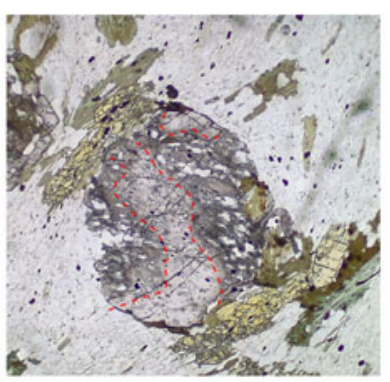

(c)

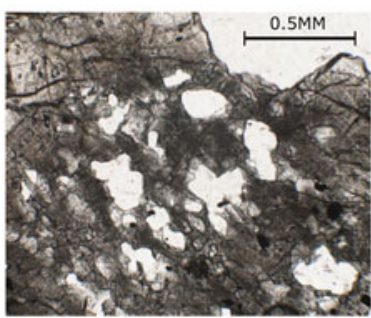

(e)

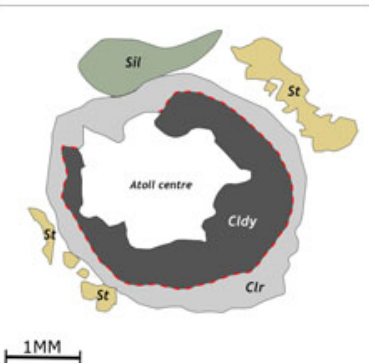

(f)

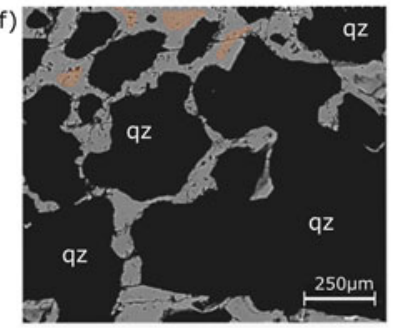

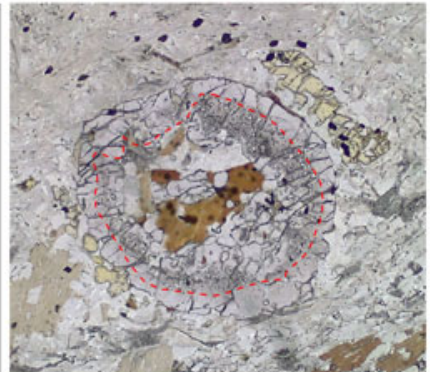

(g)

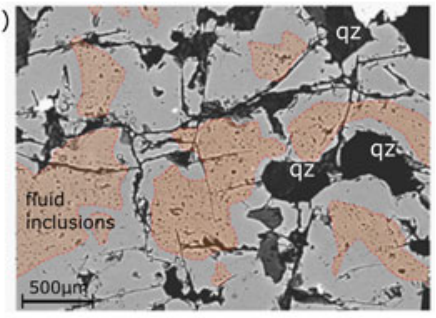

(d)

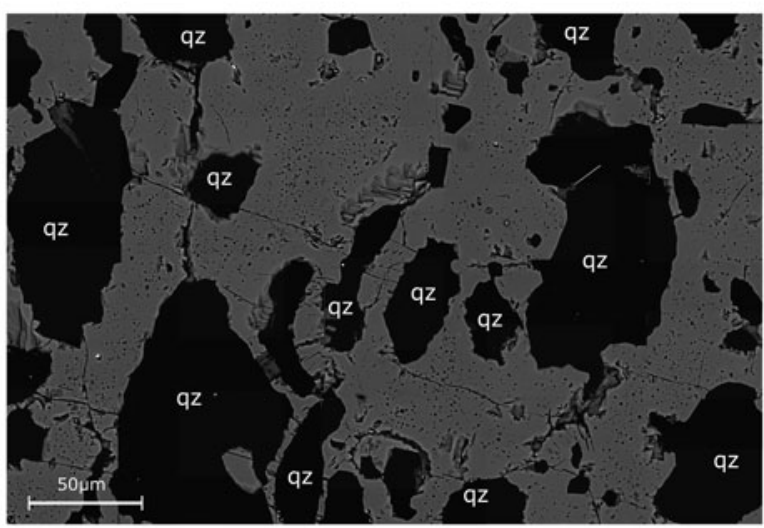

(h)

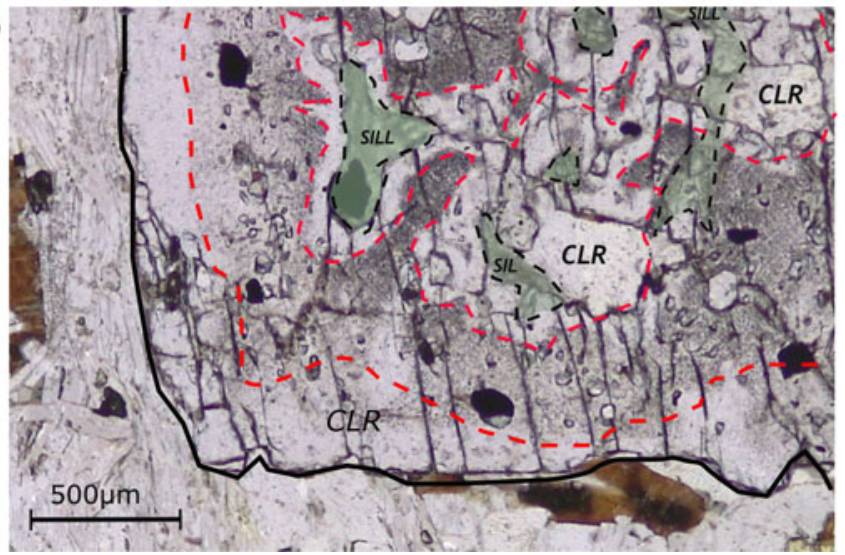

Fig. 3. Morphology of garnet, mineral abbreviations follow Warr (2021): (a) cartoon (left) and PPL image (right) of the typical geometry of cloudy (cldy) garnet bands in staurolite-zone garnet; (b-c) cloudy garnet appears darker in PPL images, containing abundant quartz inclusions and fluid inclusions; (d) BSE image of the texture of cloudy garnet in staurolite-zone schists with abundant fluid inclusions and irregularly-shaped quartz inclusions; (e) cartoon and PPL image of the typical geometry of cloudy garnet in sillimanite-zone schists; (f) variability in cloudy garnet in sillimanite-zone schists containing quartz-rich bands, areas rich in fluid inclusions are highlighted in orange; $(\mathrm{g})$ quartz-poor bands in sillimanite-zone cloudy garnet with fluid inclusion-rich areas highlighted in orange; and (h) secondary clear garnet margins and inclusion rims in sillimanite-zone garnet. Sillimanite (Sil) is highlighted in green and red dashed lines delineate secondary clear (Clr) garnet.

ilmenite $\sim 1$ vol.\% is lower than within staurolite-zone garnet, $\sim 1.5$ vol. $\%$.

Compositional transects of cloudy garnet are complicated by high inclusion and fracture abundance resulting in analyses of garnet compositions in transects difficult. Spot analyses reveal low $\mathrm{Ca}$ and high $\mathrm{Mg}$ contents, consistent with staurolite-zone schists.

\section{Secondary clear garnet}

Secondary clear garnet is exclusive to the sillimanite-zone schists. It is texturally similar to primary clear garnet containing $<0.1$ vol.\% fluid inclusions. Secondary clear garnet occurs locally surrounding mineral inclusions and infilled fractures, and at most porphyroblast margins (Fig. 3h). Within the porphyroblast interiors, the development of secondary clear garnet is widest adjacent to sillimanite inclusions, locally reaching $>500 \mu \mathrm{m}$. Here the garnet may contain a high fracture density and some irregularly-shaped inclusions, typical of cloudy garnet, though almost no fluid inclusions. In contrast, secondary clear garnet at the porphyroblast margins generally contains no mineral or fluid inclusions and very limited fractures (Fig. 3h). Such margins are typically $100-200 \mu \mathrm{m}$ in width, reaching $>1 \mathrm{~mm}$ adjacent to fibrolite mats in the matrix.

Secondary clear garnet has consistently low $\mathrm{Mn}$ and $\mathrm{Ca}$ contents, whereas $\mathrm{Mg}$ and $\mathrm{Fe}$ contents are high and more variable. Most notably, grossular contents in primary clear garnet are $\sim 10 \mathrm{~mol} \%$, decreasing to $\sim 5 \mathrm{~mol} \%$ in cloudy garnet, and $<5$ mol.\% in secondary clear garnet (Fig. 5).

\section{Zircon abundance and morphology}

Zircon occurs as two distinct populations, micro-zircon (Fig. 6a, b), and detrital zircon (Fig. 6d-f), distinguishable on the basis of their internal structure and size. Detrital zircon displays an internal structure in BSE images, indicative of growth over multiple events (Hoskin and Schaltegger, 2003) and are typically subhedral-anhedral. Micro-zircons are very fine grained, typically euhedral-to-subhedral and display no obvious internal structure (Dempster et al., 2008). A plot of all zircon sizes analysed produces a trimodal distribution (Fig. 7). There is a large peak for $<1 \mu \mathrm{m}^{2}$, which is interpreted to represent micro-zircon and a 
(a)

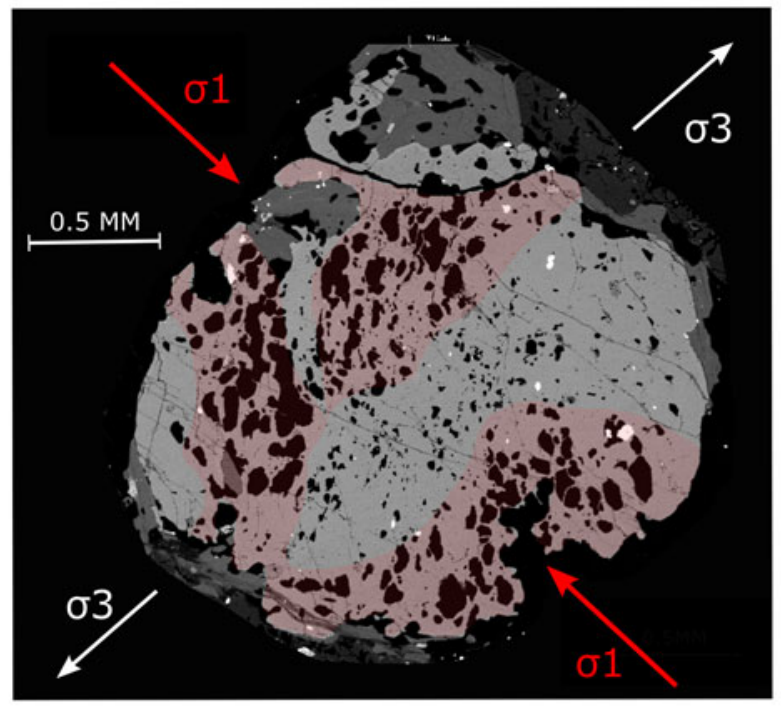

(c) Fluid inclusions

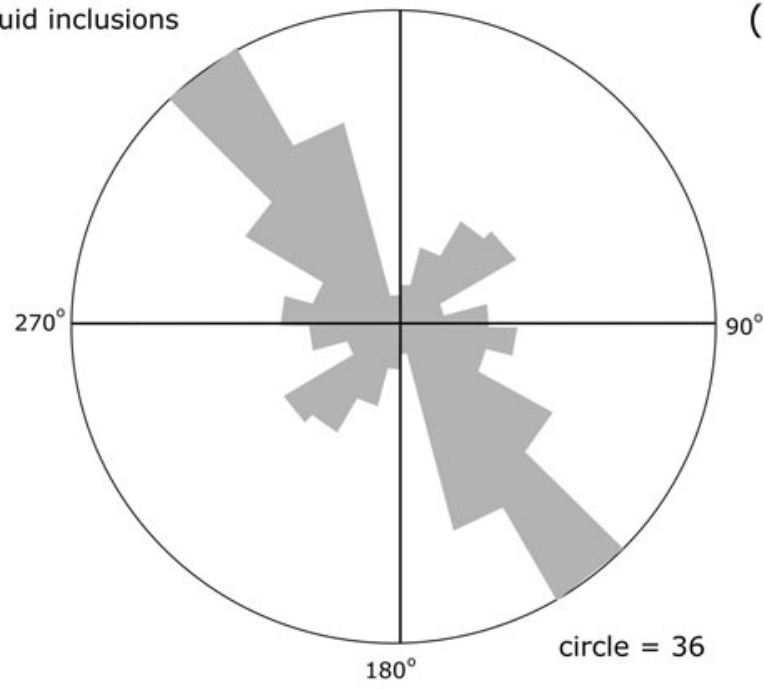

(b)

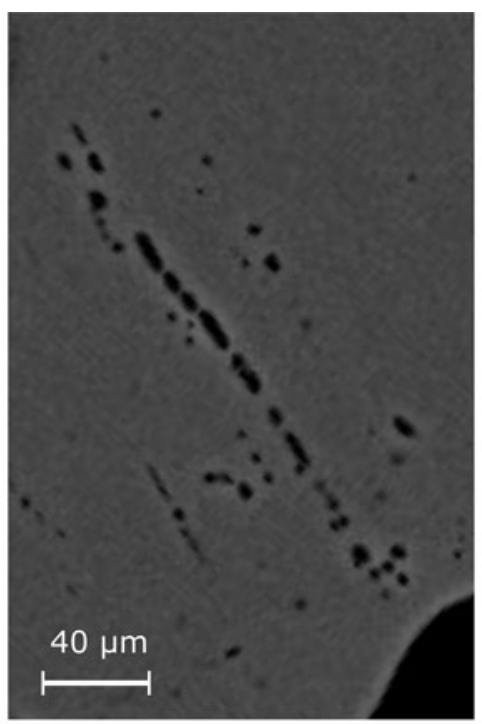

(d) Fractures

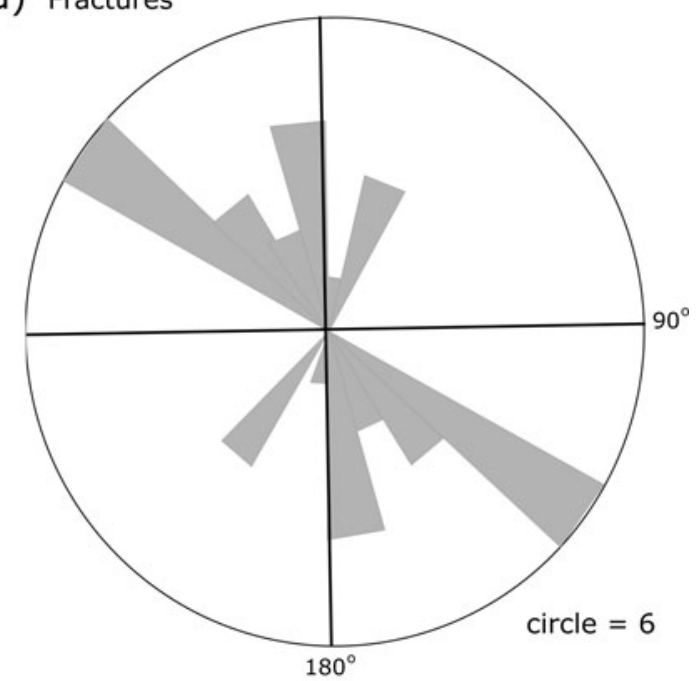

Fig. 4. Alignment of fluid inclusions in GR01-9. (a) BSE image of garnet GR01-9 with cloudy domains highlighted in orange. The remaining garnet is clear. The major tensile and compressive stress planes are shown. (b) BSE image of fluid inclusion alignment. (c) Alignment of fluid inclusions within cloudy garnet, and (d) alignment of main fractures.

smaller peak for $>3 \mu \mathrm{m}^{2}$ representing detrital zircon, above this size the internal structure is visible in BSE imaging allowing distinction. Zircon in the $1-3 \mu \mathrm{m}^{2}$ range cannot be classified easily, and such zircon is henceforth excluded from further analysis and interpretation, however attention was paid to ensure there were no systematic changes to the proportion of these unclassified grains. Within the analysed sections, 1967 zircons were characterised: 1352 micro-zircons, 351 detrital zircons and 282 unclassified zircons.

\section{Zircon in staurolite-zone schists}

\section{Zircon in the matrix}

The micaceous matrix in GR01 contains 60 micro-zircons per $\mathrm{mm}^{2}$ whereas the quartzofeldspathic matrix contains 27 micro-zircons per $\mathrm{mm}^{2}$. Zircon represents 5.2 vol.\% of the matrix, both detrital and micro-zircon. Outgrowths (cf. Hay and Dempster, 2009) are rarely present on detrital grains, though are typically $<1 \mu \mathrm{m}$ (Fig. 6e).
Most micro-zircons occur as inclusions within grains, 91\%, whereas $71 \%$ of detrital zircons are located on grain boundaries. Within the micaceous matrix, $>50$ vol. $\%$ of the micro-zircons are hosted by muscovite and $>60$ vol. $\%$ in the quartzofeldspathic matrix are hosted in quartz. The amount of detrital zircon and micro-zircon within each phase is proportional to the modal mineralogy of the matrix, with the notable exception of retrograde chlorite, which contains detrital zircon but no micro-zircon.

\section{Zircon in primary clear garnet}

The matrix contains fewer micro-zircons than garnet, GR02 contains 29 micro-zircons per $\mathrm{mm}^{2}$ whereas adjacent garnet GR02-5 contains 72 micro-zircons per $\mathrm{mm}^{2}$. In contrast, garnet contains fewer detrital zircons than the matrix (Fig. 8), matrix GR02 contains 22 detrital zircons per $\mathrm{mm}^{2}$ whereas garnet GR02-5 contains 18 detrital zircons per $\mathrm{mm}^{2}$. Garnet GR02-1 that overgrew quartzofeldspathic matrix contains 30 micro-zircons per $\mathrm{mm}^{2}$, the 
(a)

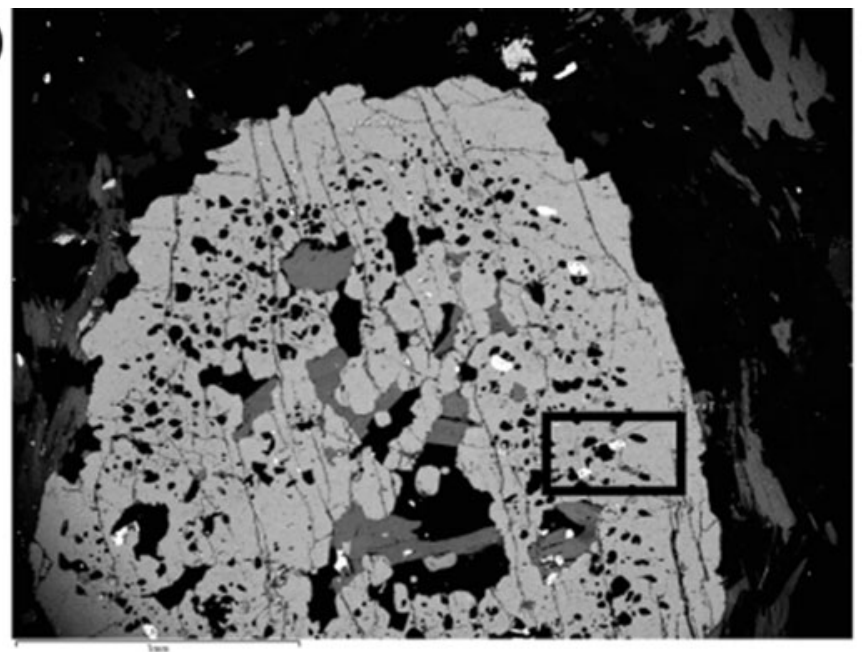

(b)

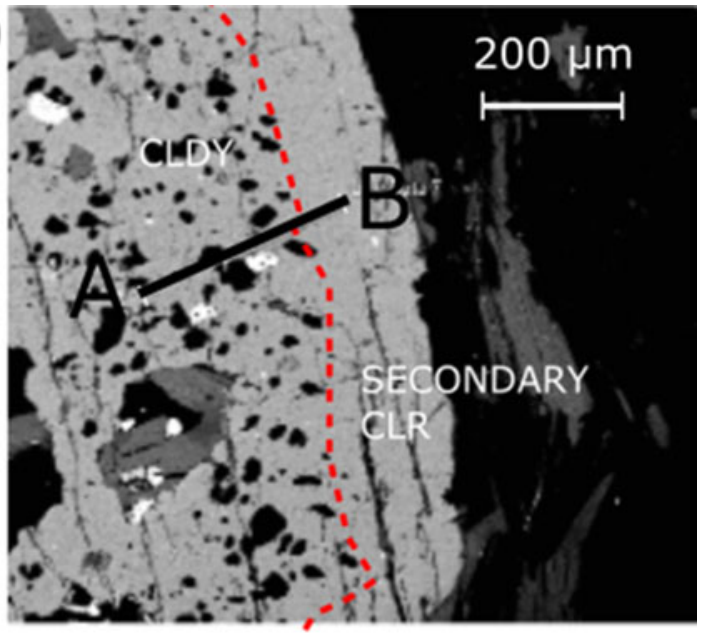

(c)

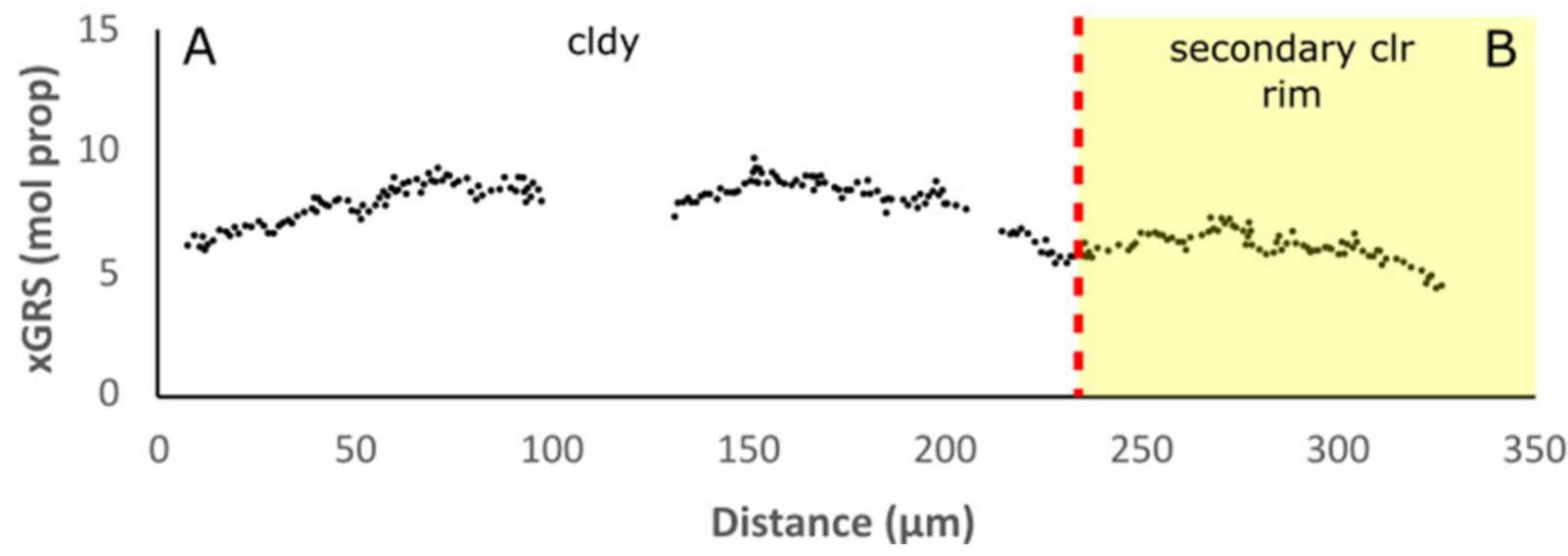

Fig. 5. Re-equilibrated composition of secondary clear mineral inclusion rims in UGRO-4. (a) BSE image of UGR0-4 and analysed area; (b) BSE image of transect A-B with the secondary clear garnet margin delineated in red; and (c) transect A-B where xGRS represents the molecular proportion of calcium-rich grossular component of garnet.

same porphyroblast that overgrew micaceous matrix contains 73 micro-zircons per $\mathrm{mm}^{2}$. In the matrix there are $15-20 \%$ more micro-zircons in micaceous layers than in the adjacent quartzofeldspathic matrix, garnet that overgrows the former contains $25-50 \%$ more micro-zircons than garnet which overgrows the quartzofeldspathic matrix (Fig. 8).

Zircon shows no systematic variation in its distribution from the core to the rim of garnet, additionally there is no change in morphology with zircon maintaining a consistent size distribution. The amount of zircon within garnet porphyroblasts in the same polished section varies considerably, GR02-1 contains 46 micro-zircons per $\mathrm{mm}^{2}$ whereas GR02-5 contains almost double that amount, (72 micro-zircons per $\mathrm{mm}^{2}$ ). Garnet porphyroblasts which contain more detrital zircon also contain more micro-zircons (Fig. 8). Micro-zircons display a spatial link to detrital zircon and ilmenite, with most micro-zircons occurring $<100 \mu \mathrm{m}$ from detrital inclusions.

\section{Zircon in cloudy garnet}

Cloudy garnet contains on average 65 vol.\% fewer micro-zircons than primary clear garnet in the same porphyroblast (Table 2). In GR01-9 primary clear garnet contains 96 micro-zircons per $\mathrm{mm}^{2}$ and cloudy garnet contains just 31 micro-zircons per $\mathrm{mm}^{2}$. Micro-zircons represent $27 \mu \mathrm{m}^{2}$ per $\mathrm{mm}^{2}$ of primary clear garnet, whereas within cloudy garnet micro-zircons comprise $9 \mu \mathrm{m}^{2}$ per $\mathrm{mm}^{2}$ (Table 2).

In cloudy garnet $62 \%$ of the micro-zircons are $<0.3 \mu \mathrm{m}^{2}$, whereas in primary clear garnet $45 \%$ are $<0.3 \mu \mathrm{m}^{2}$ in size (Fig. 9). Cloudy garnet contains a smaller proportion of fine detrital zircon $<30$ per $\mathrm{mm}^{2}$ and more $>50$ per $\mathrm{mm}^{2}$ zircon. Within cloudy garnet $35 \%$ of the micro-zircons are in fluid and mineral inclusions, whereas the remainder are hosted in garnet, compared to $<1 \%$ of micro-zircon hosted by inclusions in primary clear garnet.

\section{Zircon in sillimanite-zone schists}

Zircon in the matrix

The micaceous matrix contains on average 32 micro-zircons per $\mathrm{mm}^{2}$ and 5 detrital zircons per $\mathrm{mm}^{2}$. The quartzofeldspathic matrix contains less zircon, 21 micro-zircons per $\mathrm{mm}^{2}$ and 4 detrital zircons per $\mathrm{mm}^{2}$. Zircon comprises $<3 \%$ of the matrix of these schists. In the sillimanite-zone matrix $98 \%$ of the micro-zircon occurs as inclusions within single grains, whereas only $25 \%$ of the detrital zircons are hosted within single grains in the matrix. Quartz predominantly hosts micro-zircon in the quartzofeldspathic matrix and muscovite in the micaceous matrix. Chlorite contains no microzircon, although it is present in low modal abundances in these schists (Table 1). Most detrital zircons contain very thin outgrowths 
(a)

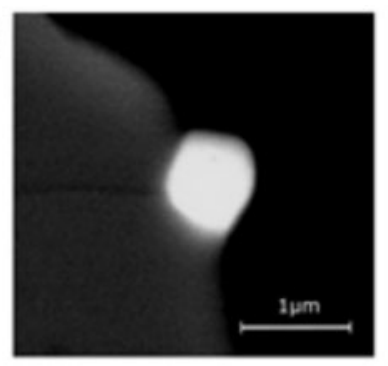

(b)

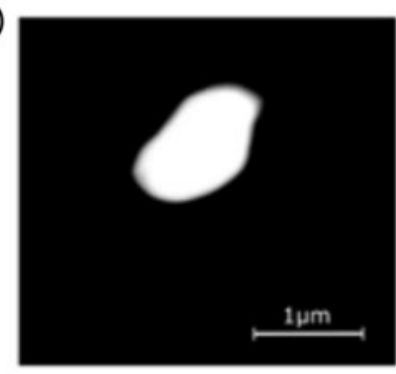

(d)

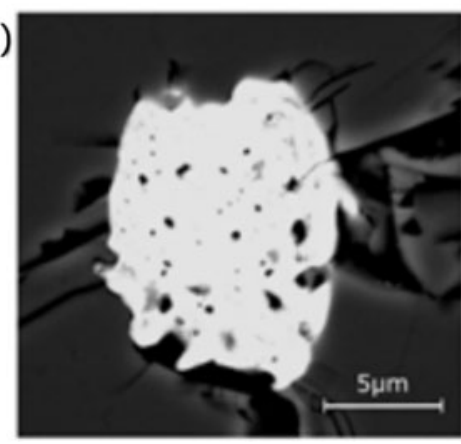

(c)
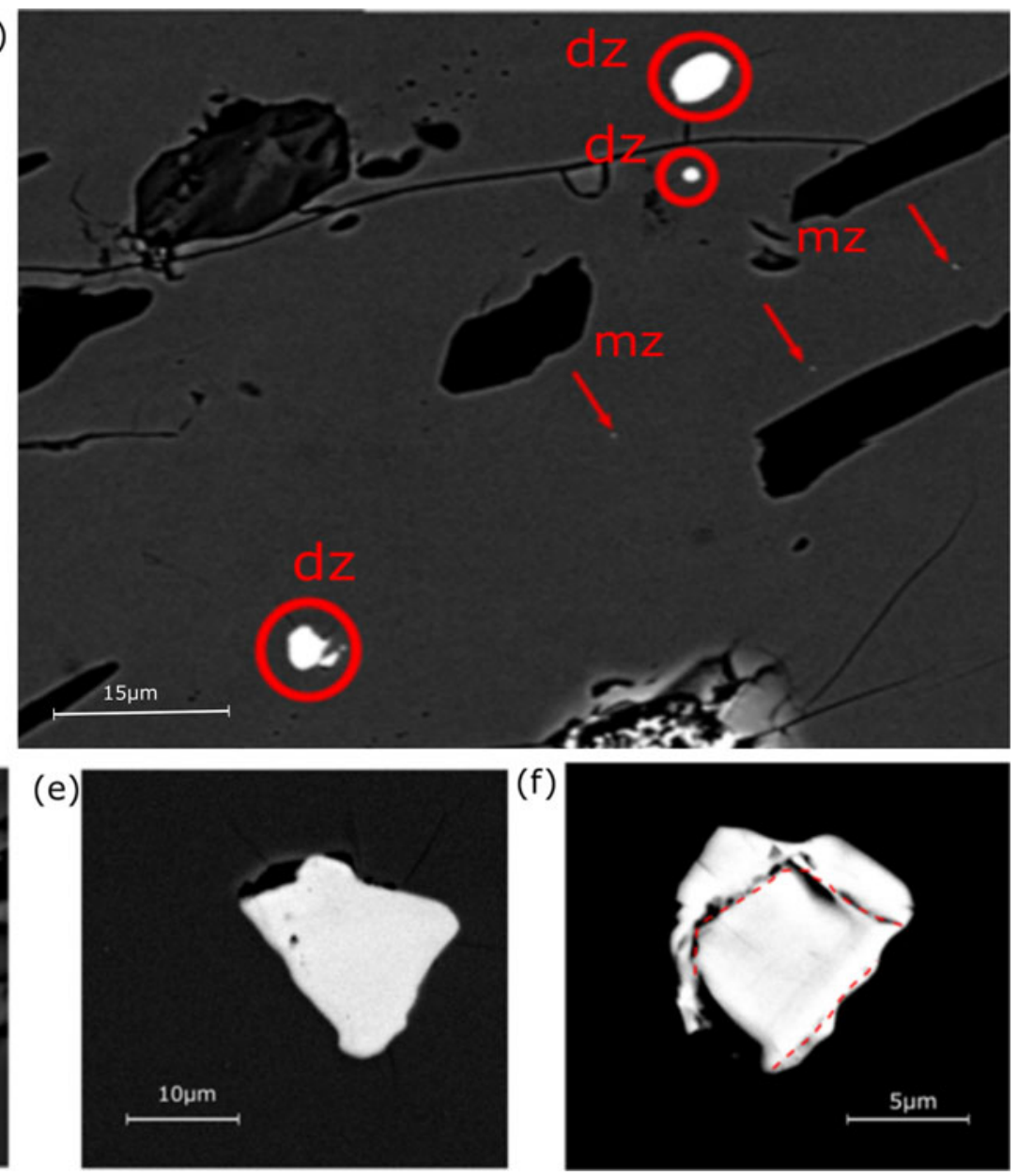

(f)

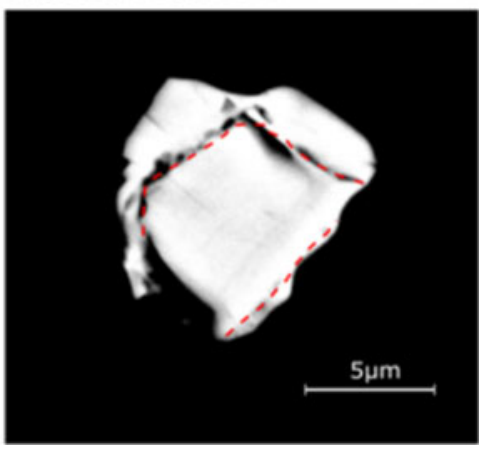

Fig. 6. Zircon morphology in Leven Schist: (a-b) BSE images of micro-zircon; (c) BSE image of detrital zircon (dz) and micro-zircon (mz) in situ in clear garnet; (d) altered detrital zircon; (e) detrital zircon in staurolite-zone schist GR01 with no outgrowths; (f) detrital zircon in cloudy garnet in sillimanite-zone schist UGR0 showing thin outgrowths.

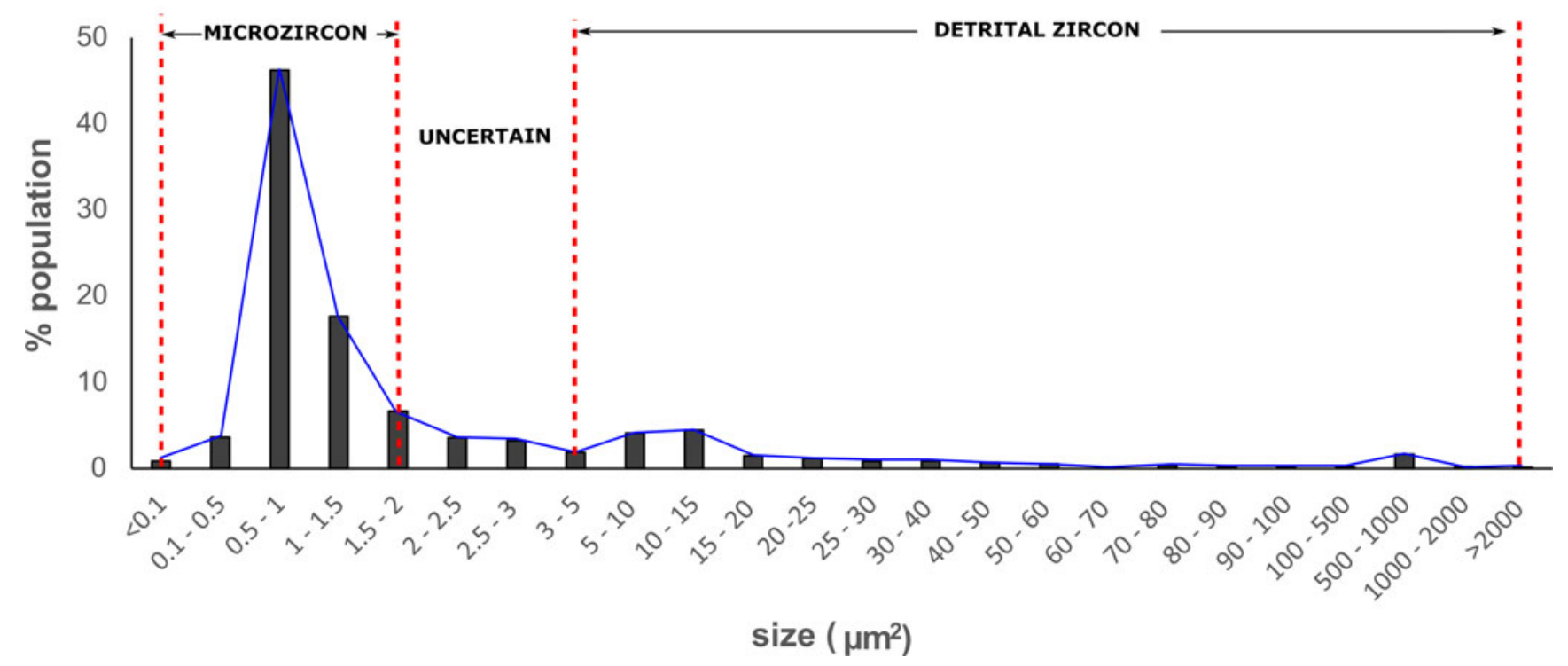

Fig. 7. Trimodal size-distribution chart based on the area $\left(\mu \mathrm{m}^{2}\right)$ of zircons collected from staurolite and sillimanite-zone Leven Schists. 


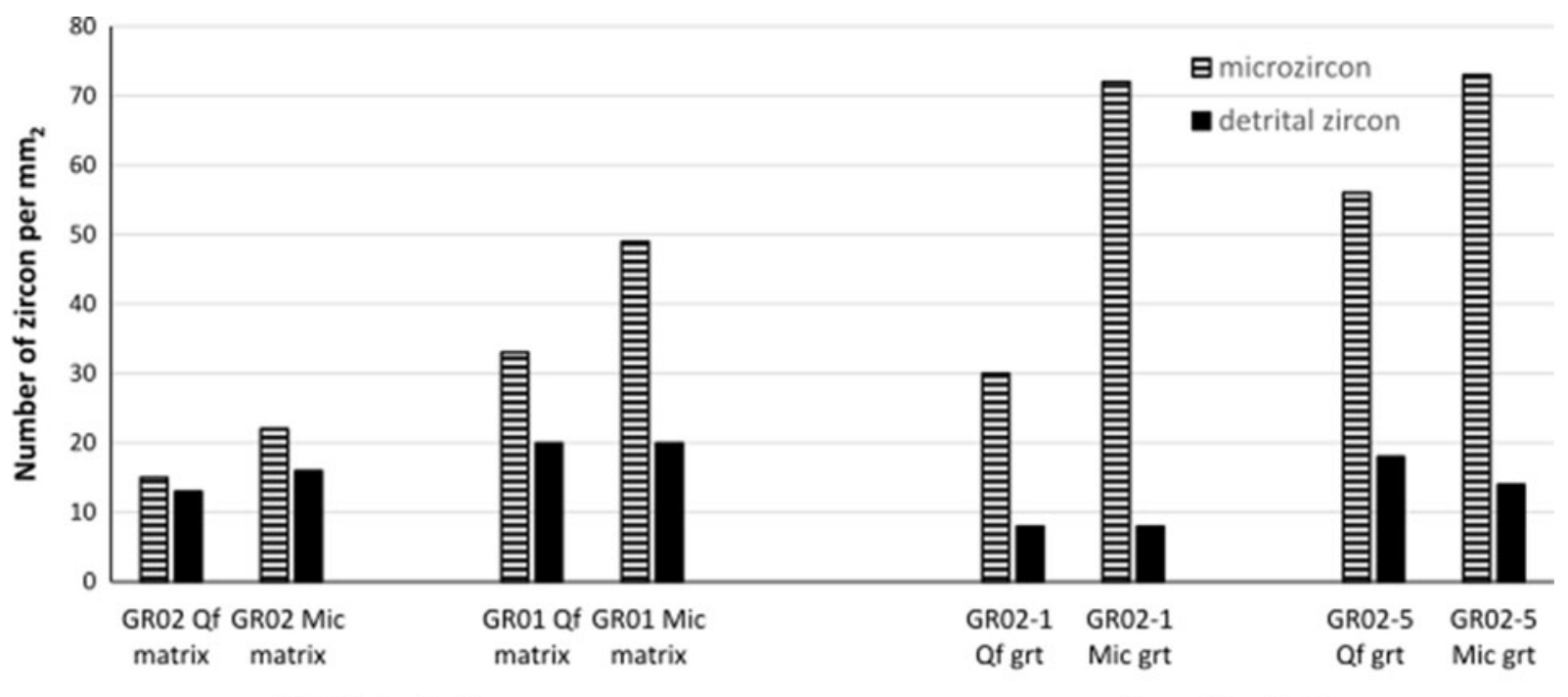

Matrix-hosted

Garnet-hosted

Fig. 8. Zircon abundance in quartzofeldspathic (Qf) and micaceous (Mic) matrix in sample GR02 and GR01 compared with zircon abundance in garnet that overgrows Qf and Mic matrix in GR02-1 and GR01-9.

Table 2. Zircon abundance within each phase of garnet in staurolite-zone and sillimanite-zone schists.

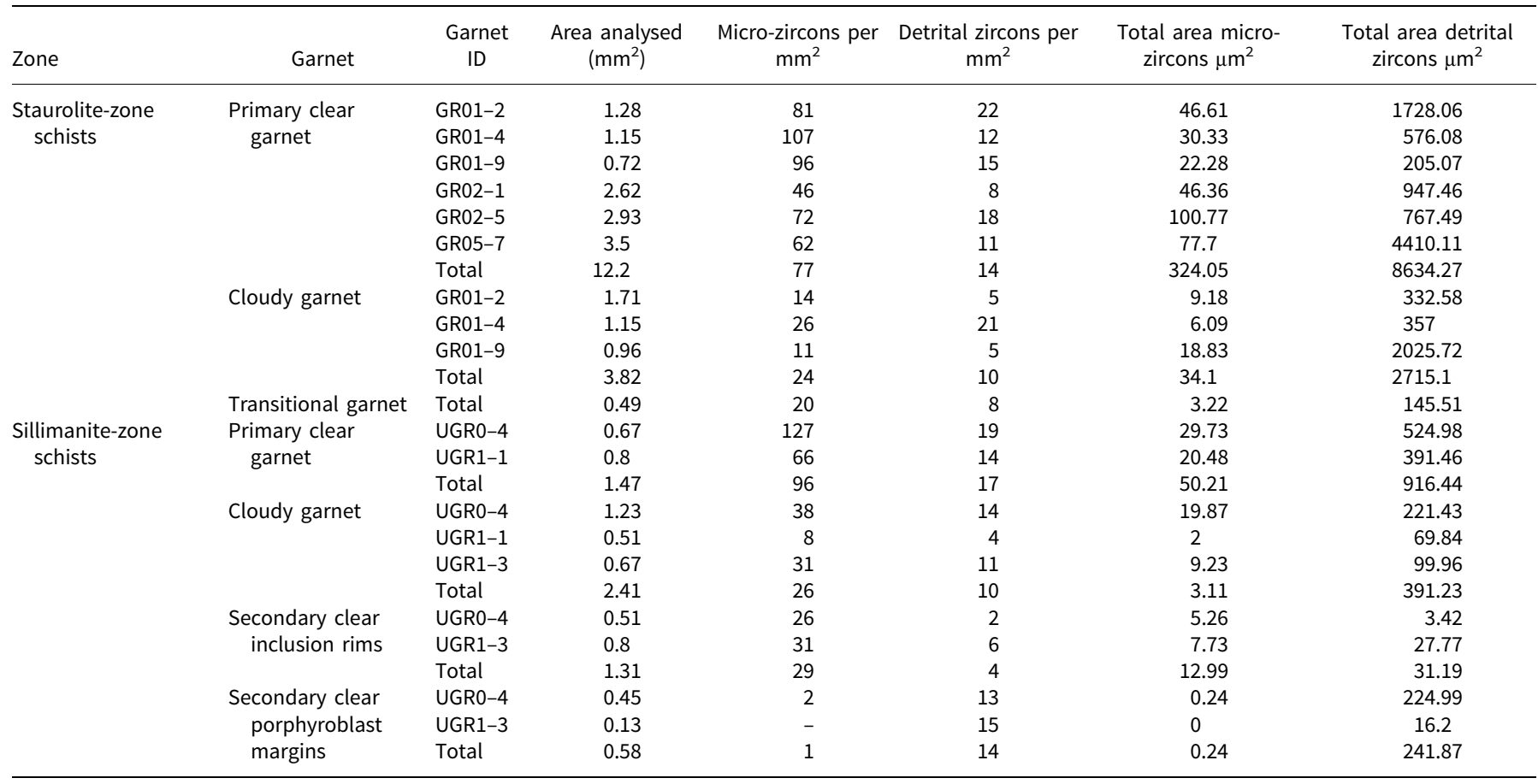

typically $<1 \mu \mathrm{m}$, though occasionally reaching a few $\mu \mathrm{m}$ in width (Fig. 6e), and which probably formed in situ as the outgrowth morphology typically follows grain boundaries in the matrix.

\section{Zircon in primary clear garnet}

There is very limited primary clear, unmodified garnet in the sillimanite-zone schists. Primary clear garnet in UGR1-1 contains similar micro-zircon abundances to garnet which overgrew the quartzofeldspathic matrix in the staurolite-zone schists. However, compositional layering in the sillimanite-zone schists is less obvious and thus inclusion banding within garnet that overgrows the more finely interbedded sediments is less obvious. Micro-zircon and detrital zircon show a spatial link to fractures, with detrital zircons commonly occurring within fractures and micro-zircons occurring $<10 \mu \mathrm{m}$ from fractures in UGR1-1. In comparison a random distribution of inclusions produces a theoretical average distance of $200 \mu \mathrm{m}$ between zircon inclusions and the nearest fracture.

\section{Zircon in cloudy garnet}

Cloudy garnet has a similar micro-zircon abundance to that in the staurolite-zone schists, much lower than within primary clear 


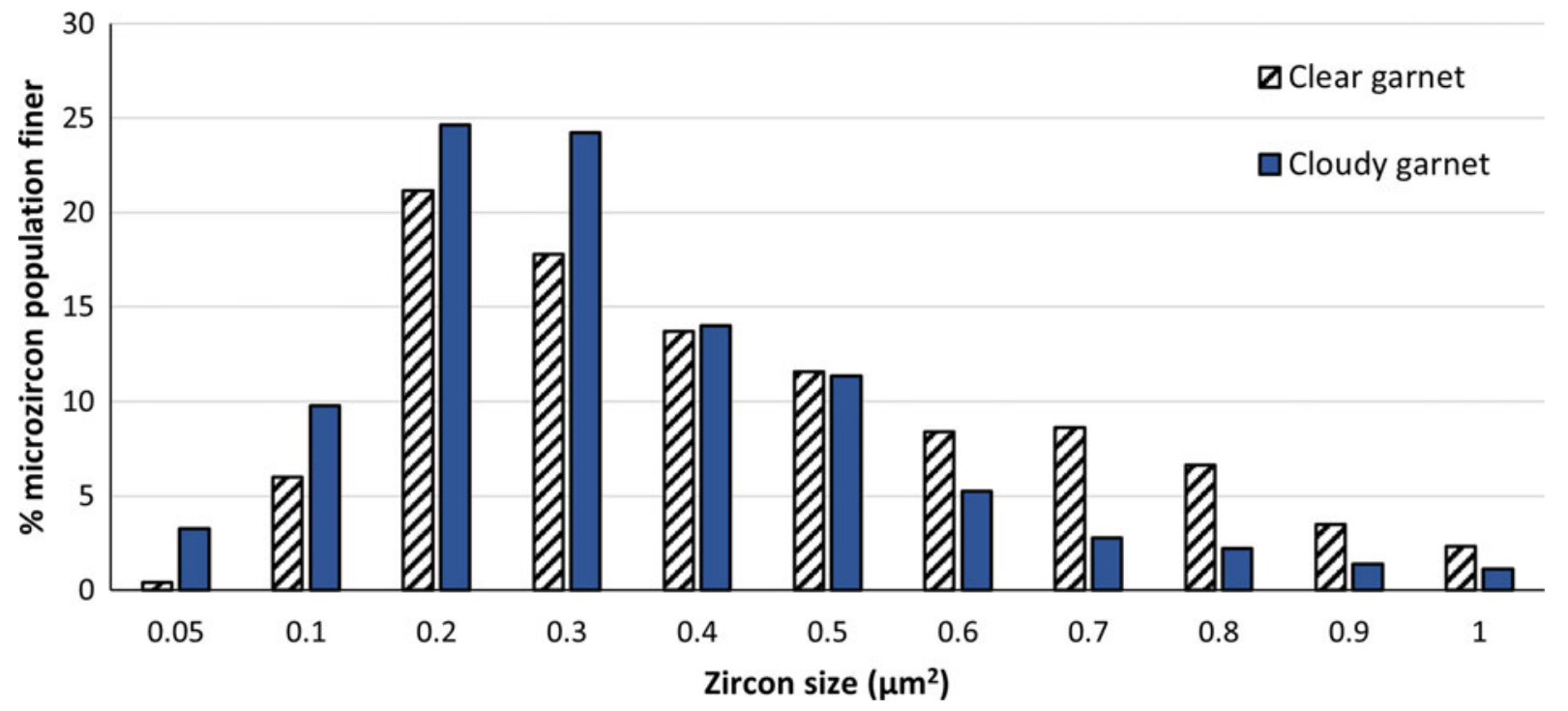

Fig. 9. Micro-zircon size distribution (area, in $\mu \mathrm{m}^{2}$ ) in clear and cloudy garnet in staurolite-zone schists.

garnet (Table 2). Micro-zircons are especially rare in all sillimanite-zone schists owing to the abundance of cloudy garnet.

Micro-zircons occur predominantly in fluid inclusions, in porphyroblast UGR0-4 $82 \%$ of micro-zircons are contained in fluid inclusions. Outgrowths on detrital zircon are relatively common in cloudy garnet, though they are generally $<10 \mu \mathrm{m}$ thick. Cloudy garnet in sillimanite-zone schists contain quartz-rich bands, these quartz-rich bands contain even fewer micro-zircons. Micro-zircons are more abundant in cloudy garnet immediately surrounding quartz-rich bands.

Zircon in secondary clear garnet

Secondary clear garnet that forms locally surrounding inclusions and at porphyroblast rims (Dempster et al., 2019), contains the fewest micro-zircons $\left(15\right.$ per $\left.\mathrm{mm}^{2}\right)$ (Table 2). Secondary clear garnet at porphyroblast rims contains 9 vol.\% less micro-zircon than secondary clear garnet surrounding mineral inclusions within garnet interiors (Fig. 3). Detrital zircon abundance in secondary clear garnet is consistent with that of cloudy garnet averaging 9 detrital zircons per $\mathrm{mm}^{2}$, only slightly lower than in primary clear garnet. There is no difference in micro-zircon morphology or abundance between cloudy garnet and secondary clear garnet.

\section{Discussion}

\section{Staurolite-zone garnet}

The variable nature of the inclusion trails within garnet porphyroblasts correlates with the nature of the original sedimentary layering. Quartz inclusion-rich primary clear garnet overgrew the quartzofeldspathic matrix and ilmenite inclusion-rich garnet overgrew the micaceous matrix. Primary clear garnet has undergone limited postgrowth modification, preserving the major divalent cation growth zoning, thus volume diffusion appears to be essentially ineffective at these metamorphic conditions (Hollister, 1966; Caddick et al., 2010; Baxter et al., 2017; Dempster et al., 2017).

Cloudy garnet forms as a result of coupled dissolutionreprecipitation during staurolite formation (Dempster et al., 2017). Following this, cloudy garnet contains $\sim 38$ vol.\% more inclusions. Paired with increased fracture abundance this enables the transport of material away in the fluid phase. Coupled dissolution-reprecipitation may be focussed in quartz inclusionrich garnet owing to the abundance of microcracks, formed radially around quartz, and grain boundaries (Gillet et al., 1984; Engleder, 1987; Whitney et al., 2000; Whitney et al., 2008). Quartz has a low bulk modulus (Wang et al., 2015) compared to garnet (Leitner et al., 1980; O'Neill et al., 1991) resulting in fracturing during decompression. Microcracks can form interconnected networks, which act as fluid pathways promoting coupled dissolutionreprecipitation within garnet located in quartz-rich layers. Garnet that overgrows the micaceous matrix contains more abundant ilmenite, which has a higher bulk modulus (Wilson et al., 2005; Cunha et al., 2019) more similar to garnet, resulting in limited fracturing within garnet which has overgrown these quartz-poor layers.

Whereas some quartz inclusions in cloudy garnet might be remnants of quartz from the matrix, there is an increase in the mode of quartz within garnet following coupled dissolution-reprecipitation. The formation of quartz during this process might assist in the transport of alkalis between reactant and product phases (Konrad-Schmolke et al., 2018). Dissolution-reprecipitation of pyroxene and amphibole has been suggested to involve the formation of a silica-rich amorphous phase (Keller et al., 2006; Bukovská et al., 2015; Konrad-Schmolke et al., 2018). This amorphous phase allows the repolymerisation of product phases in addition to promoting fluid flow through the creation of grain boundaries (Konrad-Schmolke et al., 2018). The quartz inclusions in this study are crystalline, however the complex tectonothermal history of the Glen Roy rocks could potentially produce a crystalline intermediate phase during coupled dissolution-reprecipitation of garnet.

Monazite within garnet is probably metamorphic, forming at the expense of allanite at the staurolite isograd (Wing et al., 2003; Corrie and Kohn, 2008; Gregory et al., 2007; Spear, 2010). Allanite contains less Ce per mole than monazite (Ercit, 2002), as a result the volume of monazite in cloudy garnet is less. Heavy REE are more compatible with garnet (Rubatto, 2002; Bui Thi Sinh et al., 2019); thus it may incorporate some HREE from allanite instead producing LREE-enriched monazite. The increased abundance and variety of mineral inclusions in cloudy garnet is further evidence of the ability of fluids involved in coupled dissolutionreprecipitation to transport high-field-strength elements. 
Fluid inclusions form due to rapid growth in a fluid-rich environment (Crawford and Hollister, 1986). The dominant alignment of fluid inclusions is approximately parallel to extensional fractures, whereas the secondary alignment is parallel to the matrix foliation. Both planes of alignment appear to be deformationcontrolled, consistent with fracture orientation; fluid inclusions probably formed during the healing of fractures (Fig. 4). Unaligned inclusions may form asynchronously during coupled dissolution-reprecipitation, produced at an earlier stage when fluids are more available. Alternatively, evidence of alignment of fluid inclusions may be missing from samples where sections are cut $>45^{\circ}$ from the plane of alignment.

During coupled dissolution-reprecipitation, the garnet composition is modified as a result of partial re-equilibration with the fluid phase (Martin et al., 2011; Ague and Axler, 2016; Dempster et al., 2017, 2019). As coupled dissolution-reprecipitation typically forms sharp compositional boundaries (Putnis, 2009), the gradational boundary between cloudy and primary clear garnet might be indicative of later diffusive modification. Manganese undergoes rapid diffusion (Carlson, 2006) producing a gradual, sloping spessartine distribution profile between primary clear and cloudy garnet, whereas diffusion of Ca is slower (Carlson, 2006) resulting in a more abrupt grossular boundary. Cloudy garnet forms bands, which typically cross-cut compositional zoning, indicating that coupled dissolution-reprecipitation occurs irrespective of the original garnet composition and is instead focussed in fluid-rich areas, such as at crystal margins and along fractures. Most cloudy bands form along tensile planes parallel to the main extensional stress, fractures forming on this plane enable fluid access to the reactive parent garnet (Jamtveit and Austrheim, 2010; Dempster et al., 2017). Reaction fronts propagate parallel to these planes into unaltered parent garnet producing thick cloudy bands. The second common alignment of cloudy bands is parallel to the matrix fabric.

The consistent size distribution of fluid inclusions in cloudy and transitional garnet is indicative that transitional garnet formed during coupled dissolution-reprecipitation and is not a feature of textural re-equilibration. If fluid inclusions were a feature of later re-equilibration, then smaller fluid inclusions would be eradicated preferentially owing to their larger surface energy producing a population of larger fluid inclusions in transitional garnet. The development of coupled dissolution-reprecipitation in the Leven Schists is summarised in Fig. 10. The process begins at the margins of porphyroblasts and propagates towards the interior of the garnet through interconnected fractures. As the reaction interface moves into garnet interiors, fluid becomes less available primarily due to its consumption during reactions and entrapment as inclusions. As a result fewer fluid and mineral inclusions are formed in cloudy garnet with increasing distance from the original reaction interface, continuing until fluid availability falls below a threshold and the process terminates. The partial textural alteration in these zones where composition has been completely modified indicates that at staurolite-grade conditions, textural modification is less effective than compositional modification in garnet.

\section{Sillimanite-zone garnet}

In the sillimanite-zone schists the change in composition and texture in cloudy garnet mimics that within staurolite-zone garnet, meaning that all cloudy garnet probably formed synchronously during staurolite formation (Dempster et al., 2019). Products of fluid-mediated reactions exhibit higher defect densities in their lattice (Spruzeniece et al., 2017) as a result cloudy garnet is more reactive than primary clear garnet. Additionally, during coupled dissolution-reprecipitation $\mathrm{Ca}$ is released moving the sillimanite isograd to lower $P-T$ space (Dempster et al., 2019), thus schists with a large proportion of cloudy garnet are more likely to form sillimanite.

Within the sillimanite-zone schists the original sediments were probably more finely interbedded. These layers produce more channelised structures which can act as conduits (Derry, 1992; Ague, 2011). Estimates of fluid flow across layers are an order of magnitude slower than flow parallel to layering (Ferry and Gerdes, 1998). Fluid availability may therefore be higher in these schists, promoting coupled dissolution-reprecipitation and staurolite and cloudy garnet formation, and as a result sillimanite formation. Fluid availability is probably the limiting factor in the reaction process and in the less permeable staurolite-zone schists is limited, whereas in the more permeable sillimanite-zone schists coupled dissolution-reprecipitation and cloudy garnet formation is more effective. The quartz inclusion-rich cloudy garnet in sillimanite-bearing schists shares a similar morphology to cloudy zones in staurolite-zone schists, the quartz-rich bands may represent cloudy garnet forming from the initial propagation of fluid during coupled dissolution-reprecipitation at staurolite grade conditions. During the initial stages of the reaction fluid availability is higher (Putnis and Putnis, 2007), increasing the potential for quartz formation and as the process progresses and temperature increases, mineral inclusion-poor cloudy garnet forms.

Secondary clear garnet is exclusive to sillimanite-zone schists, probably forming during sillimanite growth (Dempster et al., 2019). Secondary clear garnet has a distinctive low Ca composition, indicating it represents an additional stage in garnet evolution. Calcium contents can be used locally within a porphyroblast to monitor the degree of modification of garnet at higher grade where re-equilibration occurs making textural classification complex.

Secondary clear garnet only occurs around mineral inclusions, fractures and at porphyroblast rims, all of which are potentially fluid-rich areas. Fluid availability therefore could be an important factor in the re-equilibration of garnet during sillimanite formation. Both secondary clear garnet margins and secondary clear inclusion rims have the same low $\mathrm{Ca}$, high $\mathrm{Mg}$ composition (Fig. 5), indicating that they formed under the same conditions. Porphyroblast margins are more homogeneous, mineral inclusions and fractures have been eliminated together with fluid inclusions, whereas mineral inclusion rims contain more original features with just fluid inclusions eradicated during re-equilibration. When dissolution and reprecipitation are closely coupled the product phase may be a pseudomorph of the dissolved parent phase, preserving original features through epitaxial nucleation (Putnis and Putnis, 2007; Putnis and Austrheim, 2010; Ruiz-Agudo et al., 2014). Temporal decoupling may occur at porphyroblast margins where fluid availability is higher and thus dissolution is more effective than reprecipitation. The result is the eradication of original features and precipitation of a more homogeneous garnet product.

\section{Zircon in staurolite-zone schists}

The absence of micro-zircon on grain boundaries in the matrix is probably a facet of preservation. Grain boundaries have high fluid fluxes, whereas zircon contained within grains are sheltered. The abundance of micro-zircon as inclusions in all matrix phases suggests they probably formed at the same time as their host mineral in the matrix. The abundance of micro-zircon and detrital zircon within each matrix phase is proportional to their modal 


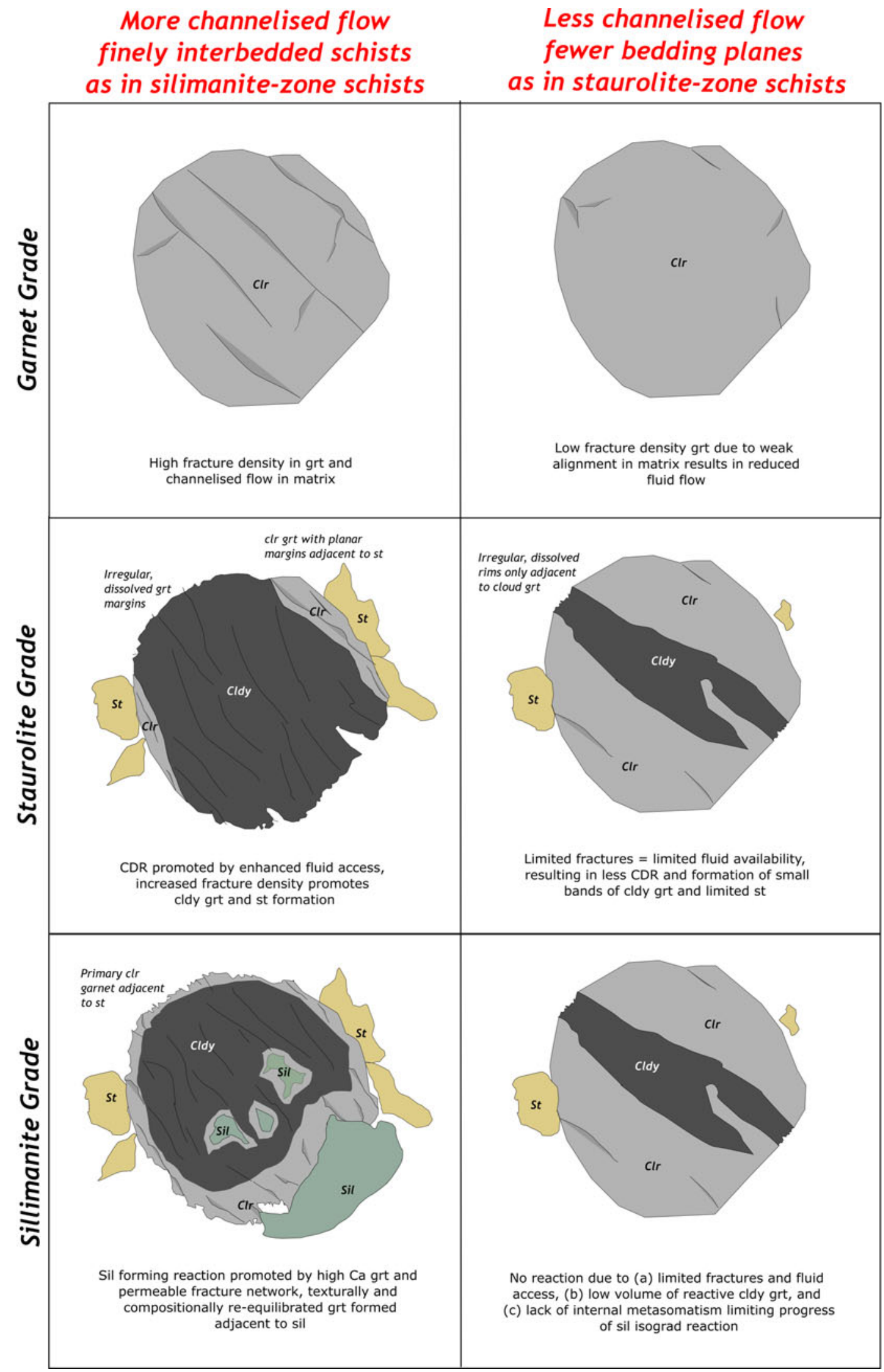

Fig. 10. Model for the progression of the sillimanite and staurolite schists with increasing grade and the potential controls on the degree and morphology of dissolution-reprecipitation. Key: Clr = clear garnet, Cldy = cloudy garnet, $C D R=$ coupled dissolution-reprecipitation. 


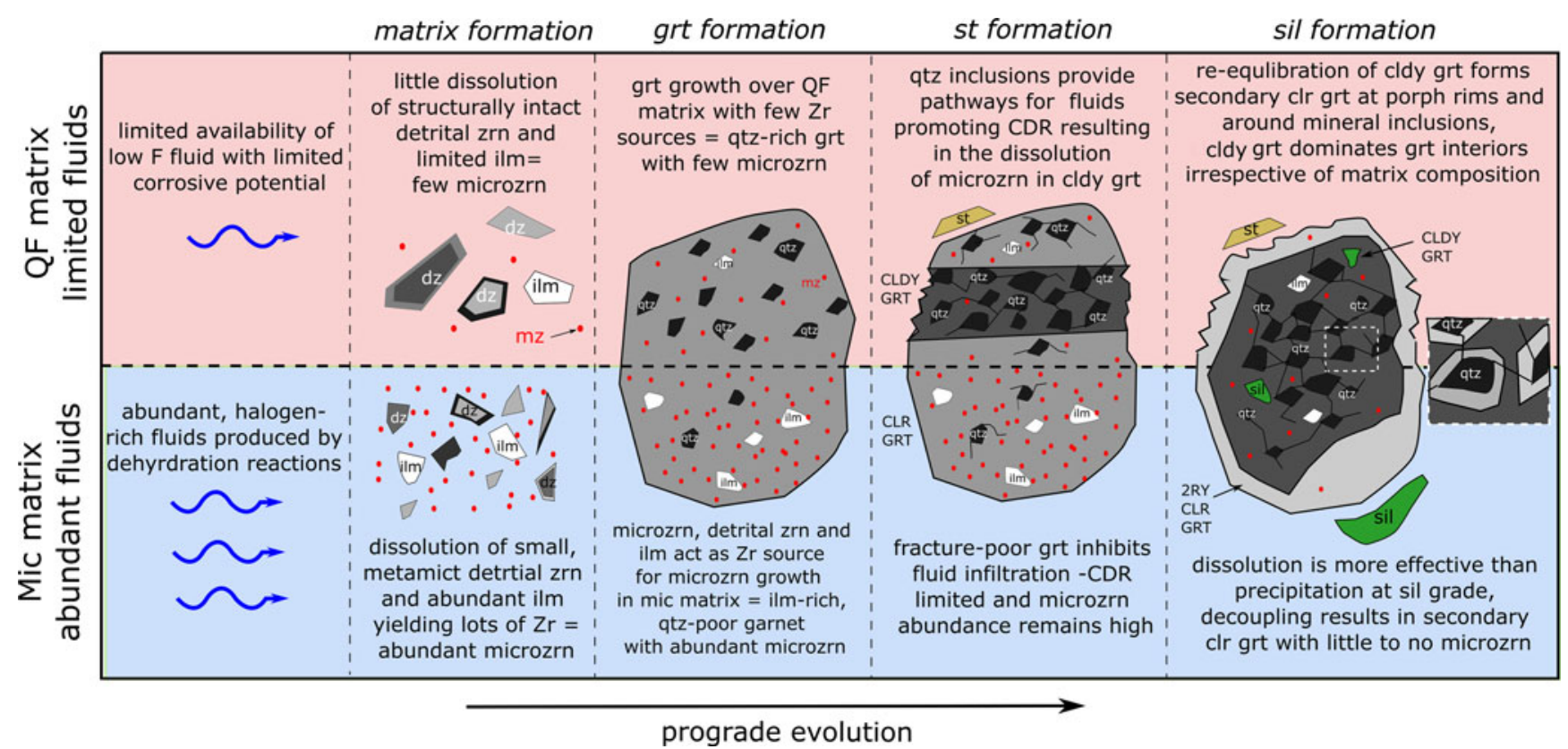

Fig. 11. Summary diagram detailing changes to micro-zircon $(\mathrm{mz})$ and detrital zircon $(\mathrm{dz})$ abundance and distribution at each stage of the reaction history through the fluid-poor quartzofeldspathic (QF) matrix and fluid-rich micaceous (Mic) matrix in primary clear (CLR) garnet, cloudy (CLDY) garnet and secondary clear (2RY CLR) garnet. $\mathrm{CDR}=$ coupled dissolution-reprecipitation.

mineralogy, except for retrograde chlorite which contains a high proportion of detrital zircon and no micro-zircon. During prograde metamorphism, fluids are generated by dissolution of hydrous minerals, however during retrograde metamorphism fluid enters the rock from an external source (Etheridge et al., 1983; Connolly and Thompson, 1989; Yardley et al., 2000). The conduits exploited for fluid infiltration during retrogression may be exploited to remove fluid before it has the chance to become saturated in $\mathrm{Zr}$ and reprecipitate as zircon, resulting in chlorite with no micro-zircon.

The quartzofeldspathic matrix contains fewer micro-zircons than the micaceous matrix, this might be the result of lower fluid availability in quartzofeldspathic layers and or lower $\mathrm{Zr}$ fluxes for new zircon growth (Fig. 11). The micaceous matrix may produce halogen-enriched fluids during dehydration reactions, capable of preferentially dissolving and transporting $\mathrm{Zr}^{4+}$ (Rasmussen, 2005). Pelitic host rocks appear to contain a larger population of finer grained and potentially more metamict detrital zircon which could yield more Zr through dissolution (Dempster and Chung, 2013). In contrast the larger, more structurally intact detrital zircon within quartzofeldspathic host rocks are perceived to be less reactive. Additionally, the micaceous matrix contains abundant ilmenite, which can contain 1000s ppm Zr (Bingen et al., 2001; Charlier et al., 2007; Bea et al., 2006), and could act as a $\mathrm{Zr}$ source. A combination of these three factors produces a microzircon-rich micaceous matrix and micro-zircon-poor quartzofeldspathic matrix (Fig. 11).

Garnet contains more micro-zircon than the matrix, indicative that during garnet growth micro-zircons are crystallising at the growing edge in addition to those captured from the matrix, which grew prior to garnet growth. Micro-zircon nucleating at the growing edge of garnet are probably encapsulated quickly resulting in a finer grained population than in the matrix. Micro-zircon formation is constant throughout porphyroblast growth as there is no change in micro-zircon morphology and abundance concentrically within the garnet. The matrix mineralogy controls the amount of $\mathrm{Zr}$ available for potential zircon growth, when garnet overgrows the micaceous matrix it accentuates the contrast of micro-zircon abundance across the micaceous and quartzofeldspathic matrix (Fig. 11). In the mica-rich matrix either: (a) ilmenite recrystallises at the garnet isograd releasing Mn for garnet growth (Woodsworth, 1977; Jiang et al., 1996) and $\mathrm{Zr}$ for zircon; or (b) finer grained fragments of the more metamict detrital zircon are more reactive and dissolve further as fluid is released during garnet forming reactions (Dempster and Chung, 2013). Formation of abundant micro-zircon in garnet is therefore a result of micro-zircon encapsulation from the matrix but also formation of new micro-zircon where the $\mathrm{Zr}$ is derived from dissolution of detrital and micro-zircon at the garnet growing face and potentially the recrystallisation of ilmenite.

Cloudy garnet consistently contains much fewer micro-zircons than primary clear garnet. Coupled dissolution-reprecipitation preferentially occurs in garnet that overgrows the quartzofeldspathic matrix silicate inclusion-rich garnet, due to increased fracturing and hence fluid availability. Cloudy garnet contains fewer micro-zircon than primary clear garnet that overgrew the quartzofeldspathic matrix. The original lithology might in part account for a lower volume of micro-zircon in cloudy garnet however it is not solely responsible indicating that coupled dissolutionreprecipitation results in significant micro-zircon loss by dissolution with metamorphic grade. Cloudy garnet contains finer grained micro-zircon than primary clear garnet; such zircon would be the initial phase eradicated during dissolution owing to their higher surface energy. There is no disparity in microzircon size between garnet that overgrew the quartzofeldspathic and micaceous matrix, hence it is possible that during coupled dissolution-reprecipitation a new population of finer grained micro-zircon form at the expense of coarser micro-zircon in the original host primary clear garnet. As coupled dissolutionreprecipitation is a fast process (Putnis and Putnis, 2007; 
Ruiz-Agudo et al., 2014), the reaction front propagates quickly encapsulating zircon in new garnet preventing further growth and producing finer grained micro-zircon.

\section{Zircon in sillimanite zone}

The decrease in the abundance of micro-zircon on grain boundaries in the matrix could be a facet of coarsening of the matrix, however it is also probably influenced by dissolution of microzircon at higher temperatures along grain boundaries, which act as fluid pathways.

Primary clear garnet in sillimanite-zone schists contains less zircon than primary clear garnet in staurolite-zone schists (Table 2) and the zircon is distributed unevenly, with microzircon and detrital zircon occurring in close proximity to fractures, typically $<10 \mu \mathrm{m}$. Zircon has a higher bulk modulus, 223-250 GPa (Özkan and Jamieson, 1978; Hazen and Finger, 1979; Marqués et al., 2006), than garnet, 170 GPa (Leitner et al., 1980). Micro-zircons subsequently form close to detrital zircon during garnet growth indicative that detrital zircons are an important source of Zr. This close spatial relationship may also enable the formation of outgrowths in sillimanite-zone schists where micro-zircon nucleates close to detrital grains as transport ability is increased at higher temperatures.

Cloudy garnet in sillimanite-zone schists contain similar proportions of zircon to staurolite-zone cloudy garnet. Quartz inclusion-rich cloudy bands in garnet form in fluid-rich marginal areas of porphyroblasts and contain abundant fractures, it is unsurprising these quartz-rich areas of cloudy garnet contain fewer micro-zircon than in quartz-poor cloudy garnet owing to their greater dissolution potential. Zircon dissolved in quartz inclusion-rich cloudy garnet produces $\mathrm{Zr}$-rich fluids, which are transported into adjacent quartz-poor cloudy garnet producing abundant micro-zircon in areas proximal to quartz-rich garnet. Micro-zircons are commonly hosted in fluid inclusions, indicating that they have formed in a fluid-rich environment and/or that micro-zircon hosted within inclusions are preferentially protected.

Secondary clear garnet has undergone an additional stage of modification associated with sillimanite formation and contains fewer micro-zircons. Micro-zircon dissolution seems particularly effective during the production of secondary clear garnet at porphyroblast margins, owing to increased fluid availability from the matrix, whereas inclusion rims in porphyroblast interiors are more sheltered from fluids. The consistent size distribution of micro-zircon between cloudy garnet and secondary clear garnet is indicative that no new micro-zircons are precipitated during sillimanite growth. It is instead possible a small proportion of micro-zircons formed in early events are preserved. Dissolution of detrital zircon is ineffective during sillimanite formation, secondary clear garnet contains similar detrital zircon abundances as cloudy garnet. At high temperatures, original metamict detrital zircon begins to undergo annealing producing more stable detrital zircon (Balan et al., 2001; Nasdala et al., 2001; Hay and Dempster, 2009) which is less likely to be dissolved, yielding limited Zr.

Sillimanite-zone schists contain more evidence of zircon outgrowths than within the staurolite-zone schists. The sillimanitebearing schists have undergone further dehydration reactions producing abundant fluids, which when paired with the higher temperatures, make $\mathrm{Zr}$ transportation more effective. Increased transport rates and higher $\mathrm{Zr}$ equilibrium volumes promote the formation of outgrowths around existing detrital grains instead of micro-zircon neoblasts.
There is a cumulative 79\% loss in the amount of micro-zircon following coupled dissolution-reprecipitation during staurolite formation and dissolution during sillimanite formation. Although it is currently not possible to do an overall assessment of the $\mathrm{Zr}$ budget in these rocks, the loss of micro-zircon certainly does not seem to be balanced by an increase in the abundance and size of zircon outgrowths on large detrital grains. Though there is an increase in the abundance of outgrowths within sillimanitezone schists these are very thin and only present on some detrital zircon. Zirconium is being removed from zircon and potentially reincorporated into another phase for which it is not an essential component. Ilmenite and rutile have been shown to incorporate $\mathrm{Zr}$ in relatively large abundances, with rutile containing up to 1360 ppm Zr (Cave et al., 2015) and ilmenite Zr-contents generally less than rutile but proving slightly more difficult to characterise and highly dependent on silica content (Bea et al., 2006). A detectable amount of $\mathrm{Zr}$ is redistributed in these schists, if the zircon removed from the average $3 \mathrm{~mm}$ garnet following staurolite and sillimanite growth was incorporated solely into ilmenite and rutile, in the abundance they are present, it would represent an easily detectable amount of $>1$ wt.\%. If it were incorporated within the garnet lattice it would represent $185 \mathrm{ppm} \mathrm{Zr}$. It is important to note there is a grade dependence on how $\mathrm{Zr}$ is distributed. Sillimanite-zone schists contain evidence of overgrowths and rutile partially replaces ilmenite, potentially accounting for a large amount of $\mathrm{Zr}$ lost from micro-zircon dissolution. Whereas staurolite-zone schists have not undergone the ilmenite-rutile transition and contain almost no evidence of outgrowths, the distribution of $\mathrm{Zr}$ in these schists following coupled dissolution-reprecipitation is more uncertain.

\section{Conclusions}

Analysis of garnet and zircon behaviour during prograde metamorphism reveals important controls on coupled dissolutionreprecipitation processes and the importance of fluid availability on progressive metamorphism.

Coupled dissolution-reprecipitation of garnet is controlled initially by lithological layering and deformation. Garnet porphyroblasts that overgrow more quartzofeldspathic matrix layers generate quartz dominated inclusion suites, subsequently producing more fractures or conduits within the garnet and increasing fluid availability. Once access to the core of garnet is secured porphyroblast composition appears to be the dominant factor controlling metamorphic reaction progress, preferentially dissolving the Mn-rich core producing atoll garnet.

As metamorphic grade increases, dissolution and reprecipitation appear to become decoupled owing to faster dissolution rates. The result is the precipitation of a more homogeneous product phase with the removal of original features, as is the case with secondary clear garnet.

The mineralogy of the matrix impacts the micro-zircon abundance by influencing original detrital zircon populations and fluid availability, and therefore potential Zr fluxes.

Micro-zircon abundance increases during initial garnet formation though decreases with every stage of fluid-mediated modification in the reaction history. A detectable quantity of $\mathrm{Zr}$ is removed from zircon and is probably incorporated into other mineral phases - probably rutile and ilmenite, and potentially garnet, owing to lattice relaxation at higher temperatures.

Detrital zircon abundance decreases during garnet formation but remains consistent during any subsequent modification, 
potentially a result of increased stability caused by annealing of metamict grains at higher temperatures.

Retrogression is effective at dissolving micro-zircon however $\mathrm{Zr}$ is transported out of the system before new $\mathrm{Zr}$ can precipitate producing chlorite with no micro-zircon.

Much of the metamorphic history of these schists is influenced strongly by fluid availability and controlled by fine scale lithological variation in the matrix promoting or inhibiting channelisation and fluid availability. It has even been suggested the staurolite- and sillimanite-zone schists at Glen Roy have undergone identical $P-T-X$ histories however fluid availability promotes or inhibits the production of index minerals (Dempster et al, 2019).

Acknowledgements. This work was carried out at the University of Glasgow. The authors thank Robert MacDonald for his assistance with sample preparation. Special thanks are given to Dr Thomas Mueller, Dr Freya George and Dr Roger Mitchell for their thorough and thoughtful reviews, which helped improve and refine this work.

Supplementary material. To view supplementary material for this article, please visit https://doi.org/10.1180/mgm.2021.97

\section{References}

Ague J.J. (2011) Extreme channelization of fluid and the problem of element mobility during Barrovian metamorphism. American Mineralogist, 96, 333-352.

Ague J.J. and Axler J.A. (2016) Interface coupled dissolution-reprecipitation in garnet from subducted granulites and ultrahigh-pressure rocks revealed by phosphorous, sodium, and titanium zonation. American Mineralogist, 101(7), 1696-1699.

Altree-Williams A., Pring A., Ngothai Y. and Brugger J. (2015) Textural and compositional complexities resulting from dissolution-reprecipitation reactions in geomaterials. Earth-Science Reviews, 150, 628-651.

Atherton M.P. (1968) The variation in garnet, biotite and chlorite composition in medium grade pelitic rocks from the Dalradian, Scotland, with particular reference to the zonation in garnet. Contributions to Mineralogy and Petrology, 18, 347-371.

Balan E., Neuville D.R., Trocellier P., Fritsch E., Muller J. and Calas G. (2001) Metamictization and chemical durability of detrital zircon. American Mineralogist, 86(9), 1025-1033.

Baxter E.F., Caddick M.J. and Dragovic B. (2017) Garnet: A rock-forming mineral petrochronometer. Pp. 469-533 in: Petrochronology: Methods and Applications (M.J. Kohn, M. Engi and P. Lanari, editors). Reviews in Mineralogy and Geochemistry, 83. Mineralogical Association of America and the Geochemical Society, Chantilly, Virginia, USA.

Bea F., Montero P. and Ortega M. (2006) A LA-ICP-MS evaluation of Zr reservoirs in common crustal rocks: Implications for $\mathrm{Zr}$ and $\mathrm{Hf}$ geochemistry, and zircon-forming processes. The Canadian Mineralogist, 44, 693-714.

Bingen B., Austrheim H. and Whitehouse M. (2001) Ilmenite as a source for zirconium during high grade metamorphism? Textural evidence from the Caledonides of Western Norway and implications for zircon geochronology. Journal of Petrology, 42, 355-375.

Bui Thi Sinh V., Osanai Y, Lenz C., Nakano N., Adachi T., Belousova E. and Kitano I. (2019) Gem-quality zircon megacrysts from placer deposits in the Central Highlands, Vietnam- potential source and links to Cenozoic alkali basalts. Minerals, 9, 18 pp., https://doi.org/10.3390/min9020089.

Bukovská Z., Wirth R. and Morales L.F. (2015) Pressure solution rocks: focussed ion beam/transmission electron microscopy study on orthogneiss from South Armorican Shear Zone, France. Contributions to Mineralogy and Petrology, 170(31), $13 \mathrm{pp}$.

Caddick M.J., Konopásek J. and Thompson A.B. (2010) Preservation of garnet growth zoning and the duration of prograde metamorphism. Journal of Petrology, 51, 2327-2347.

Carlson W.D. (2006) Rates of $\mathrm{Fe}, \mathrm{Mg}, \mathrm{Mn}$ and $\mathrm{Ca}$ diffusion in garnet. American Mineralogist, 91, 1-11.
Cave B.J., Stepanov A.S., Craw D., Large R.R., Halpin J.A. and Thompson J. (2015) release of trace elements through sub-greenschist facies breakdown of detrital rutile to metamorphic titanite in the Otago Schist, New Zealand. The Canadian Mineralogist, 53, 379-400.

Chakraborty S. and Ganguly J. (1991) Compositional zoning and cation diffusion in garnets. Pp. 120-175 in: Diffusion, Atomic Ordering, and Mass Transport: Selected Topics in Geochemistry (Ganguly, J., editor). Springer-Verlag, New York.

Charlier B., Skär Ǿ., Korneliussen A., Duchesne J.C. and Auwera V. (2007) Ilmenite composition in the Tellnes Fe-Ti deposit, SW Norway: fractional crystallization, postcumulus evolution and ilmenite zircon relation. Contributions to Mineralogy and Petrology, 154, 119-134.

Connolly J.A.D. and Thompson A.B. (1989) Fluid and enthalpy production during regional metamorphism. Contributions to Metamorphic Petrology, C102, 346-366.

Corrie S.L. and Kohn M.J. (2008) Trace-element distribution in silicates during prograde metamorphic reactions: implications for monazite formation. Journal of Metamorphic Petrology, 26, 451-464.

Crawford M.L. and Hollister L.S. (1986) Metamorphic fluids: the evidence from fluid inclusions. Advances in Physical Geochemistry, 5, 1-35.

Cunha T.R., Rodrigues A.D., Rodrigues J.E., Sampaio D.V., Moulton B.J.A., da Costa R.C. and Pizani P.S. (2019) Thermal expansion, compressibility and bulk modulus of ilmenite-type CoTiO3: X-ray diffraction at high pressures and temperatures. Solid State Sciences, 88, 1-5.

Dempster T.J. (1985) Garnet zoning and metamorphism of the Barrovian Type Area, Scotland. Contributions of Mineralogy and Petrology, 89, 30-38.

Dempster T.J. and Chung P. (2013) Metamorphic zircon: tracking fluid pathways and the implications for the preservation of detrital zircon. Journal of the Geological Society, London, 170, 631-639.

Dempster T.J., Rogers G., Tanner P.W.G., Bluck B.J., Muir R.J., Redwood S.D., Ireland T.R. and Paterson B.A. (2002) Timing of deposition, orogenesis and glaciation within the Dalradian rocks of Scotland: constraints from U-Pb zircon ages. Journal of the Geological Society, 159, 83-94.

Dempster T.J., Hay D.C. and Bluck B.J. (2004) Zircon growth in slate. Geology, 32, 221-224.

Dempster T.J., Hay D.C., Gordon S.H. and Kelly N.M. (2008) Micro-zircon: origin and evolution during metamorphism. Journal of Metamorphic Geology, 26, 499-507.

Dempster T.J., La Piazza J., Taylor A.G., Beaudoin N. and Chung P. (2017) Chemical and textural equilibration of garnet during amphibolite facies metamorphism: The influence of coupled dissolution-reprecipitation. Journal of Metamorphic Geology, 35, 1111-1130.

Dempster, T.J., Gilmour M.I. and Chung P. (2019) The partial equilibration of garnet porphyroblasts in pelitic schists and its control on prograde metamorphism, Glen Roy, Scotland. Journal of Metamorphic Geology, 37, 383-399.

Derry L.A., Kaufman A.J. and Jacobsen S.B. (1992) Sedimentary cycling and environmental change in the late Proterozoic: evidence from stable and radiogenic isotopes. Geochimica et Cosmochimica Acta, 56, 1317-1329.

Engleder T. (1987) Joints and shear fractures in rocks. Pp. 27-69 in: Fracture Mechanics of Rock (Atkinson, B.K., editor). Academic, San Diego, California.

Ercit T.S. (2002) The mess that is 'allanite'. The Canadian Mineralogist, 40, 1411-1419.

Etheridge M.A., Wall, V.J. and Vernon R.H. (1983) The role of the fluid phase during regional metamorphism and deformation. Journal of Metamorphic Geology, 1, 205-226.

Ferry J.M. and Gerdes M.L. (1998) Chemically reactive fluid flow during metamorphism. Annual Review of Earth and Planetary Science, 26, 255-287.

Gastil R.G., Delisle M. and Morgan R.R. (1967) Some effects of progressive metamorphism on zircons. Bulletin of the Geological Society of America, 78, 879-906.

Gatewood M.P., Dragovic B., Stowell H.H., Baxter E.F., Hirsch D.M. and Bloom R. (2015) Evaluating chemical equilibrium in metamorphic rocks using major element $\mathrm{Sm}-\mathrm{Nd}$ isotopic age zoning in garnet, Townshend Dam, Vermont, USA. Chemical Geology, 401, 151-168.

Gillet P., Ingrin J. and Chopin C. (1984) Coesite in subducted continental crust: P-T history deduced from elastic model. Earth and Planetary Science Letters, 70, 426-436. 
Gregory C.J., Rubatto D., Allen C.M., Williams I.S., Hermann J. and Ireland T. (2007) Allanite micro geochronology: A LA-ICP-MS and SHRIMP U-Th-Pb study. Chemical Geology, 245, 162-182.

Gros K., Slaby E., Jokubaukas P., Sláma J. and Kozub-Budzyń G. (2020) Allanite geochemical response to hydrothermal alteration by alkaline, lowtemperature fluids. Minerals, 10(5), 392.

Guidotti C.V. (1974) Transition from staurolite to sillimanite zone, Rangeley Quadrangle, Maine. Geological Society of American Bulletin, 85, 475-490.

Hames W.E. and Menard T. (1993) Fluid-assisted modification of garnet composition along rims, cracks, and mineral inclusion boundaries in samples of amphibolite facies schists. American Mineralogist, 78, 338-344.

Hay D.C. and Dempster T.J. (2009) Zircon behaviour during low-temperature metamorphism. Journal of Petrology, 50(4), 571-589.

Hazen R.M. and Finger L.W. (1979) Crystal structure and compressibility of zircon at high pressure. American Mineralogist, 64, 196-201.

Hollister L.S. (1966) Contact metamorphism in the Kwoiek area of British Columbia: An end member of the metamorphic process. Bulletin of the Geological Society of America, 80, 2465-2494.

Hoskin P.W.O. and Black L.P. (2000) Metamorphic zircon formation by solidstate recrystallization of protolith igneous zircon. Journal of Metamorphic Geology, 18, 423-439.

Hoskin P.W.O. and Schaltegger U. (2003) The composition of zircon and igneous and metamorphic petrogenesis. Pp. 27-62 in: Zircon (J.M. Hanchar and P.W.O. Hoskin, editors). Mineralogical Association of America and the Geochemical Society, Chantilly, Virginia, USA.

Hutton D.H.W. and Alsop G.I. (2004) Evidence of major Neoproterozoic orogenic unconformity within the Dalradian Supergroup of NEW Ireland. Journal of the Geological Society, London, 161, 629-640.

Jamtveit B. and Austrheim H. (2010) Metamorphism: the role of fluids. Elements, 6, 153-158.

Jiang J. and Lasaga A.C. (1990) The effects of post-growth thermal events on growth-zoned garnet: implications for metamorphic P-T history calculations. Contributions to Mineralogy and Petrology, 105, 454-459.

Jiang S.Y., Palmer N.R. and Slack J.F. (1996) Mn-rich ilmenite from the Sullvian $\mathrm{Pb}-\mathrm{Zn}-\mathrm{Ag}$ deposit, British Columbia. The Canadian Mineralogist, 34, 29-36.

Keller L.M., Abart R., Wirth R., Schmid D.W. and Kunze K. (2006) Enhanced mass transfer through short-circuit diffusion: growth of garnet reaction rims at eclogite facies conditions. American Mineralogist, 91, 1024-1038.

Konrad-Schmolke M., Halama R., Wirth R., Thomen A., Klitscher N., Morales L., Schreiber A. and Wilke F.D.H. (2018) Mineral dissolution and reprecipitation mediated by an amorphous phase. Nature Communications, 9, 1637, 9 pp.

Leitner B.J., Wiender D.K. and Liebermann R.C. (1980) Elasticity of single crystal pyrope and implications for garnet solid solution series. Physics of the Earth and Planetary Interiors, 22, 111-121.

Marqués M., Florez M., Recio J.M., Gerward L. and Olsen J.S. (2006) Structure and stability of $\mathrm{ZrSiO}_{4}$ under hydrostatic pressure. Physical Review, B74, 014104.

Martin L.A.J., Ballèvre M., Boulvais P., Halfpenny A., Vandergaeghe O., Duchêne S. and Deloule, E. (2011) Garnet re-equilibration by coupled dissolution-reprecipitation evidence from textural, major element and oxygen isotope zoning of 'cloudy garnet'. Journal of Metamorphic Geology, 29, 213-231.

McLellan E. (1985) Metamorphic reactions in the kyanite and sillimanite zones of the Barrovian-type area. Journal of Petrology, 26(4), 789-818.

Nasdala L., Wenzel M., Varva G., Irmer G., Wenzel T. and Kober B. (2001) Metamictization of natural zircon: accumulation versus thermal annealing of radioactivity-induced damage. Contributions to Mineralogy and Petrology, 141, 125-144.

O’Neill B., Bass J.D., Rossman G.R., Geiger C.A. and Langer K. (1991) Elastic properties of pyrope. Physics and Chemistry of Minerals, 17, 617-621.

Özkan H. and Jamieson J.C. (1978) Pressure dependence of the elastic constants of nonmetamict zircon. Physics and Chemistry of Minerals, 2(3), 215-224.

Phillips E.R. and Key R.M. (1992) Porphyroblast-fabric relationships: an example from the Appin Group of the Glen Roy area. Scottish Journal of Geology, 28(2), 89-101.

Poldevaart A. (1955) Zircons in rocks: part 1, sedimentary rocks; part 2, igneous rocks. American Journal of Science, 253(8), 433-461.
Powell R. and Evans J.A. (1983) A new geobarometer for the assemblage biotitemuscovite-chlorite quartz. Journal of Metamorphic Geology, 1, 331-336.

Putnis A. (2009) Mineral replacement reactions. Pp. 87-124 in: Volatiles in Magmas (Michael R. Carroll and John R. Holloway, editors). Reviews in Mineralogy and Geochemistry, 30. Mineralogical Association of America, Washington DC, USA.

Putnis A. and Austrheim H. (2010) Fluid-induced processes: metasomatism and metamorphism. Geofluids, 10, 254-269.

Putnis A. and Putnis C.V. (2007) The mechanism of reequilibration of solids in the presence of a fluid phase. Journal of Solid State Chemistry, 180, 1783-1786.

Raimondo T., Payne J., Wade B., Lanai P., Clark C. and Hand M. (2017) Trace element mapping by LA-ICP-MS: assessing geochemical mobility in garnet. Contributions to Mineralogy and Petrology, 172(17), 1-17.

Rasmussen B. (2005) Zircon growth in very low grade metasedimentary rocks: evidence for zirconium mobility $\sim 250^{\circ} \mathrm{C}$. Contributions to Mineralogy and Petrology, 150, 146-155.

Richardson S.W. and Powell R. (1976) Thermal causes of the Dalradian metamorphism in the Central Highlands of Scotland. Scottish Journal of Geology, 12, 237-268.

Rooney A.D., Chew D.M. and Selby D. (2011) Re-Os geochronology of the Neoproterozoic-Cambrian Dalradian Supergroup of Scotland and Ireland: Implications for Neoproterozoic stratigraphy, glaciations and Re-Os systematics. Precambrian Research, 185, 202-214.

Rubatto D. (2002) Zircon trace element geochemistry: distribution coefficients and the link between $\mathrm{U}-\mathrm{Pb}$ ages and metamorphism. Chemical Geology, 184, 123-138.

Rubatto D. and Hermann J. (2007) Zircon behaviour in deeply subducted rocks. Elements, 3, 31-35.

Rubatto D., Williams I.S. and Buick I.S. (2001) Zircon and monazite response to prograde metamorphism in the Reynolds Range, central Australia. Contributions to Mineralogy and Petrology, 140, 458-468.

Ruiz-Agudo E., Putnis C.V. and Putnis A. (2014) Coupled dissolution and precipitation at mineral-fluid interfaces. Chemical Geology, 383, 132-146.

Smith M.P., Henderson P. and Jeffries T. (2002) The formation and alteration of allanite in skarn from the Beinn an Dubhaich granite aureole, Skye. European Journal of Mineralogy, 14, 471-486.

Spear F.S. (1991) On the interpretation of peak metamorphic temperatures in light of garnet diffusion during cooling. Journal of Metamorphic Geology, 9, 379-388.

Spear F.S. (2010) Monazite-allanite phase relations in metapelites. Chemical Geology, 279, 55-62.

Spruzeniece L., Piazolo S. and Maynard-Casely H.E. (2017) Deformationresembling microstructure created by fluid-mediated dissolutionprecipitation reactions. Nature Communications, 8, 14032, 9 pp.

Strachan R.A., Harris A.L., Fettes D.J. and Smith M. (2002) The Highland and Grampian Terranes. Pp. 96-99 in: The Geology of Scotland (N.H. Trewin, editor). The Geological Society, London.

Vonlanthen P., Fitzgerald J., Rubatto D. and Hermann J. (2012) Recrystallization rims in zircon (Valle D'Arbedo Switzerland): An integrated cathodoluminescence, LA-ICP-MS, SHRIMP and TEM study. American Mineralogist, 97, 369-377.

Vorhies S.H., Ague J.J. and Schmitt A.K. (2013) Zircon growth and recrystallization during progressive metamorphism, Barrovian zones, Scotland. American Mineralogist, 98, 219-230.

Wang W., Dunkley E., Clarke G.L. and Daczko N.R. (2014) The evolution of zircon during low-P partial melting of metapelitic rocks: theoretical predictions and a case study from Mt Stafford, Central Australia. Journal of Metamorphic Geology, 32, 791-808.

Wang J., Mao Z., Jiang F. and Duffy T.S. (2015) Elasticity of single-crystal quartz to $10 \mathrm{GPa}$. Physics and Chemistry of Minerals, 42, 203-212.

Warr L. (2021) IMA-CNMNC approved mineral symbols. Mineralogical Magazine, 85, 291-320.

Wells P.R.A. (1979) P-T conditions in the Moines of Central Highlands, Scotland. Journal of the Geological Society, London, 136, 663-671.

Whitney D.L., Cooke M.L. and Du Franc S.A. (2000) Modelling of radial microcracks at corners of inclusions in garnet using fracture mechanics. Journal of Geophysical Research, 105(B2), 2843-2853. 
Whitney D.L., Goergen E.T., Ketcham R.A. and Kunze K. (2008) Formation of garnet polycrystals during metamorphic crystallization. Journal of Metamorphic Geology, 26(3), 365-383.

Williams I.S. (2001) Response of detrital zircon and monazite, and their U-Pb isotopic systems, to regional metamorphism and host-rock partial melting, Cooma Complex, southeastern Australia. Australian Journal of Earth Sciences, 48, 557-580.

Wilson N.C., Muscat J., Mkhonto D., Ngoene P.E. and Harrison N.M. (2005) Structure and properties of ilmenite from first principles. The Academic Physical Society, Physical Review, B71, 075202, 9 pp.
Wing B.A., Ferry J.M. and Harrison T.M. (2003) Prograde destruction and formation of monazite and allanite during contact and regional metamorphism of pelites: petrology and geochronology. Contributions to Mineralogy and Petrology, 145, 228-250.

Woodsworth G.J. (1977) Homogenisation of zoned garnets from pelitic schists. The Canadian Mineralogist, 15, 230-242.

Yardley B.W.D. (1977) An empirical study of diffusion in garnet. American Mineralogist, 62, 793-800.

Yardley B.W.D., Gleeson S., Bruce S. and Banks D. (2000) Origin of retrograde fluids in metamorphic rocks. Journal of Geochemical Exploration, 69-70, 281-285. 